\title{
WestVirginiaUniversity
}

THE RESEARCH REPOSITORY @ WVU

Graduate Theses, Dissertations, and Problem Reports

2018

\section{Effects of Pre-Breeding Management on Ewe Lamb Fertility}

Sarah Nancy Carr

Follow this and additional works at: https://researchrepository.wvu.edu/etd

\section{Recommended Citation}

Carr, Sarah Nancy, "Effects of Pre-Breeding Management on Ewe Lamb Fertility" (2018). Graduate Theses, Dissertations, and Problem Reports. 5319.

https://researchrepository.wvu.edu/etd/5319

This Thesis is protected by copyright and/or related rights. It has been brought to you by the The Research Repository @ WVU with permission from the rights-holder(s). You are free to use this Thesis in any way that is permitted by the copyright and related rights legislation that applies to your use. For other uses you must obtain permission from the rights-holder(s) directly, unless additional rights are indicated by a Creative Commons license in the record and/ or on the work itself. This Thesis has been accepted for inclusion in WVU Graduate Theses, Dissertations, and Problem Reports collection by an authorized administrator of The Research Repository @ WVU. For more information, please contact researchrepository@mail.wvu.edu. 


\section{Effects of pre-breeding management on ewe lamb fertility}

\section{SARAH NANCY CARR}

Thesis submitted to the Davis College of Agriculture, Natural Resources and Design at West Virginia University in partial fulfillment of the requirements for the degree

of

Master of Science in Animal Physiology

Marlon Knights, Ph.D, Chair

Eugene Felton, Ph.D

Kevin Shaffer, Ph.D

Division of Animal and Nutritional Sciences

Morgantown, West Virginia

2018

Keywords: Ewe Lamb, Puberty, Feed Supplementation, Weight Change, Breeding Weight, Average Daily Gain, Fertility

Copyright 2018 Sarah N Carr 


\section{Abstract \\ Effects of pre-breeding management on ewe lamb fertility \\ Sarah Nancy Carr}

Ewe lambs comprise $30 \%$ of the breeding flock; however, fertility is $20-30 \%$ lower than that of an adult ewe. Lower fertility has been correlated with lower ADG, liveweight, and body composition prior to breeding and research suggests that it can be improved with proper nutritional management. The objective of this research was to evaluate the effects of pre-breeding management practices on ewe lamb fertility.

In replicate 1, 313 Dorset $X$ Texel (DT) and 74 Katahdin (KT) ewe lambs were assigned to a high $(0.68 \mathrm{~kg} / \mathrm{head} /$ day $)$ or low $(0.23 \mathrm{~kg} / \mathrm{head} /$ day $)$ grain supplementation for two months prior to breeding. Liveweights were recorded bi-weekly to calculate ADG and lifetime weight day averages (LWDA) and blood serum was collected by-weekly to determine estrous cyclicity. Half of each treatment group received progesterone pre-treatment prior to ram introduction. Estrous response was observed 96 hours and pregnancy diagnosis was performed 30 days and 60 days after synchronization. Replicate 2 consisted of $68 \mathrm{DT}$ ewe lambs supplemented high $(0.91 \mathrm{~kg} / \mathrm{head} / \mathrm{day})$ or low $(0.45 \mathrm{~kg} / \mathrm{head} / \mathrm{day})$ grain supplementation for four weeks prior to synchronization. All other aspects of the experimental design remained the same as replicate 1. Data from DT ewe lambs in replicates 1 and 2 were pooled for statistical analysis to determine the main effects of nutritional treatment, progesterone pretreatment, breeding weight category, average daily gain category, weight day average category, and each respective interaction. In all replicates, an ANCOVA with breeding age as the covariate was utilized to determine the main effects and interactions, as well as if ADG, breeding weight, and LWDA differed in ewe lambs experiencing a positive or negative reproductive outcome.

There was no significant effect of nutritional treatment or progesterone pretreatment on overall fertility in any replicate. In replicate 1, Higher lambing rates were observed in ewe lambs in the $\mathrm{H}$ than in the L ADG category $(\mathrm{P}=0.01)$. Ewe lambs that were heavier at breeding and had a higher LWDA had greater reproductive outcomes. In replicate 2, ewe lambs in the M but not H ADG category had or tended to have higher conception rate $(\mathrm{P}=0.06)$, pregnancy rate to the first service $(\mathrm{P}=0.02)$, proportion lambing $(\mathrm{P}=0.03)$ and lambing rate $(\mathrm{P}=0.06)$ than $\mathrm{L} A D G$ animal lambs. Reproductive outcomes increased with increasing LWDA for most response variables. In the pooled replicate, most reproductive performance variables were higher $(\mathrm{P}<0.01)$ in the $\mathrm{H}$ compared to the L ADG category. Ewe lambs in the $\mathrm{H}$ breeding weight category had higher $(\mathrm{P}<0.01)$ reproductive responses than ewe lambs in the $\mathrm{L}$ and $\mathrm{M}$ with ewe lambs in the $\mathrm{M}$ category having intermediate values. Ewe lambs in the $\mathrm{H}$ and $\mathrm{M}$ categories lambed for the first time at a younger age than ewes in the $\mathrm{L}$ category $(\mathrm{P}<0.01)$. Reproductive response variables increased with increasing weight day averages in most response variables, and the age at first lambing was lower in ewe lambs in the H compared to the L LWDA category $(\mathrm{P}<0.001)$. Breeding weights, ADG, and LWDA were significantly higher $(\mathrm{P}<0.05)$ in ewe lambs with a positive compared to a negative reproductive outcome for estrous response, conception rate, pregnancy to the first service, overall pregnancy rate, proportion lambing, and lambing to the first service period. Average daily gains $(169 \pm 44 \mathrm{v} 114 \pm 12 \vee 85 \pm 5 \mathrm{~g})$, breeding weights (61 $\pm 5 \vee 51 \pm 1 \mathrm{v} 44 \pm 1 \mathrm{~kg})$, and LWDA 
$(227 \pm 18$ v $189 \pm 5$ v $167 \pm 2 \mathrm{~g})$ were significantly higher $(\mathrm{P}<0.05)$ in ewe lambs having triplets and twins compared to singletons.

Increasing the level of nutritional supplementation, ADG, and LWDA can impact fertility, and sufficiently supplementing ewe lambs may allow an advanced estrous response and pregnancy to first service without relying on progesterone pretreatment. 


\section{Contents}

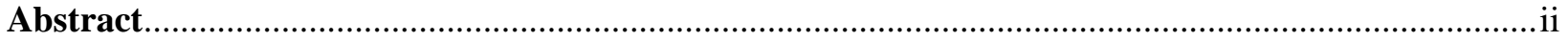

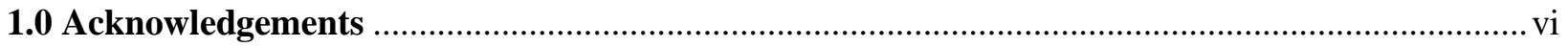

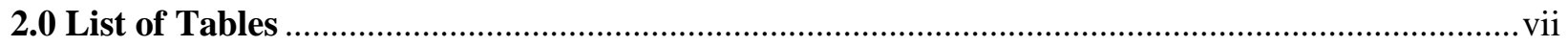

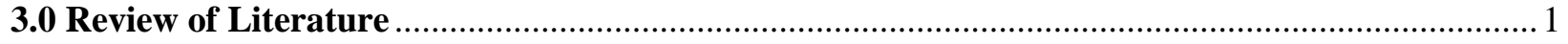

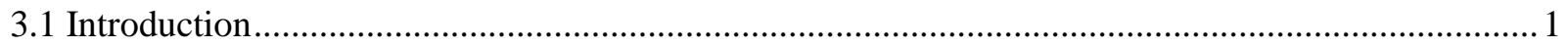

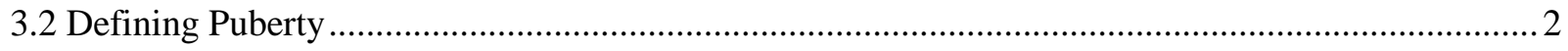

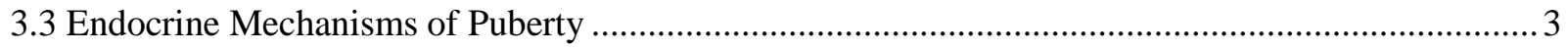

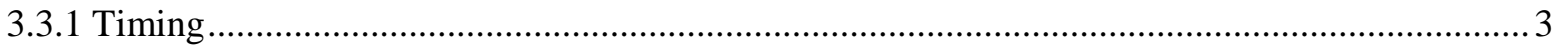

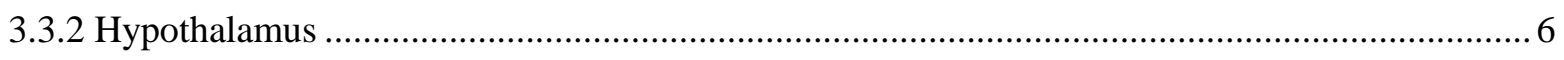

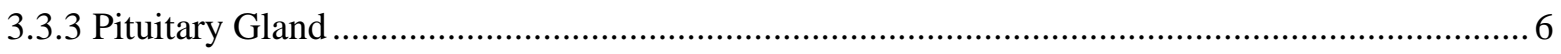

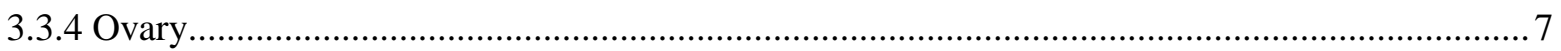

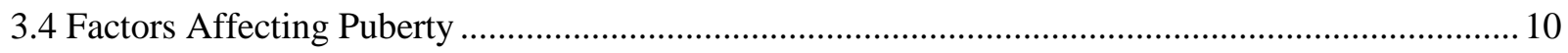

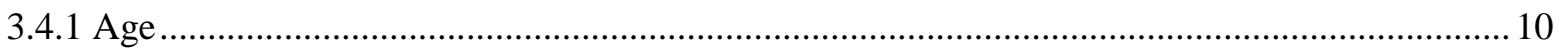

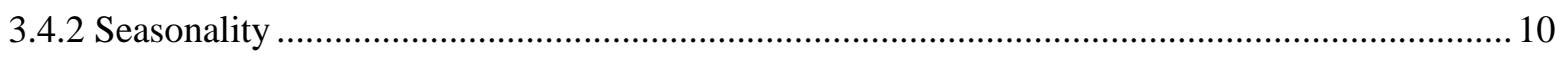

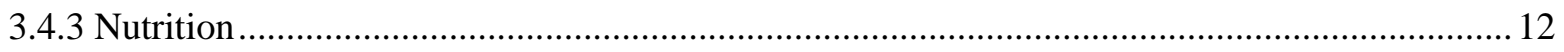

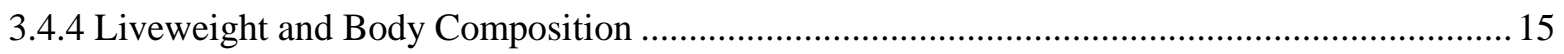

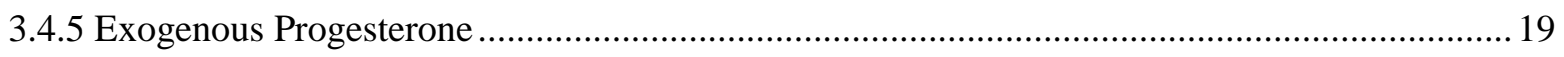

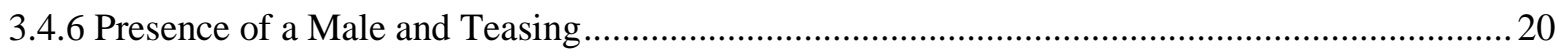

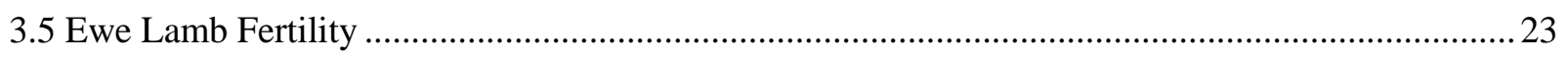

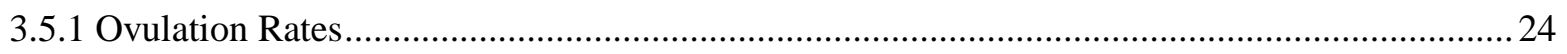

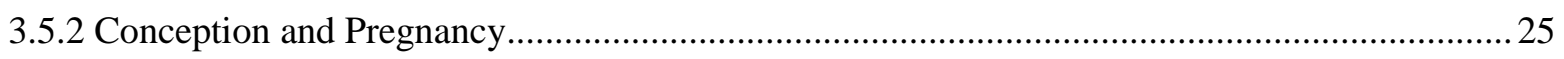

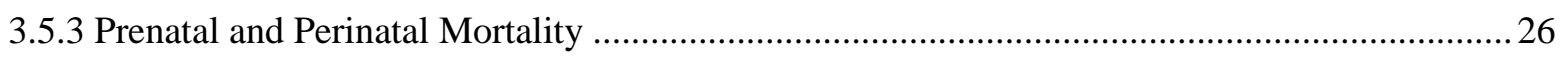

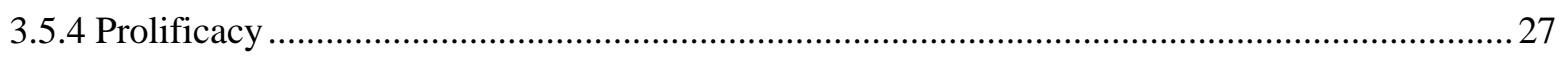

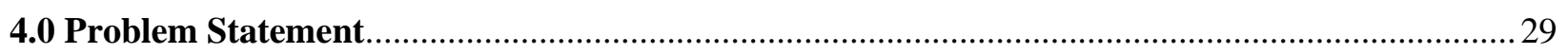

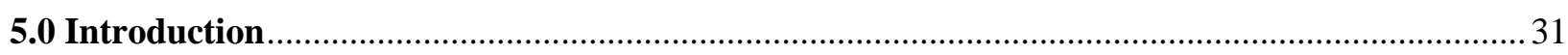

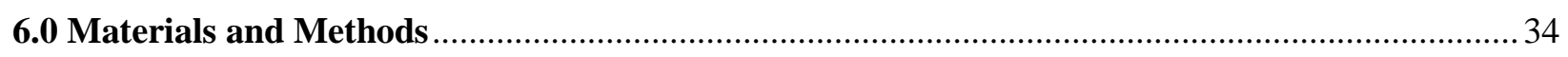

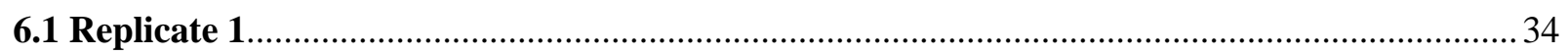

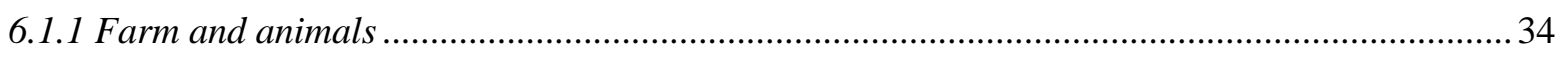

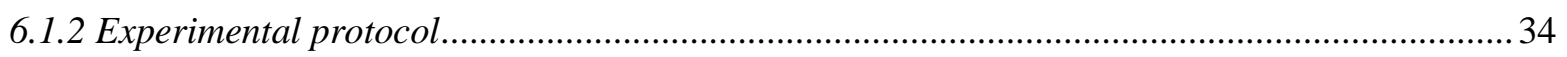

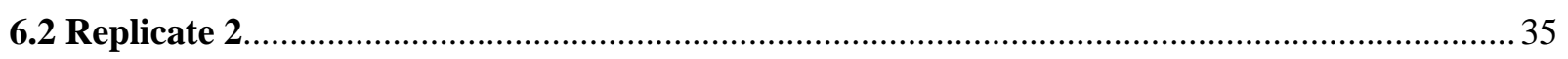

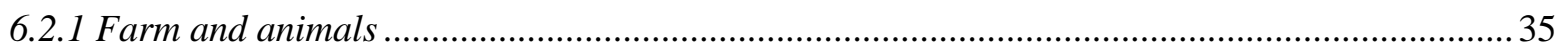

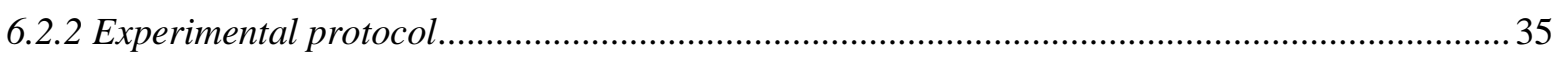

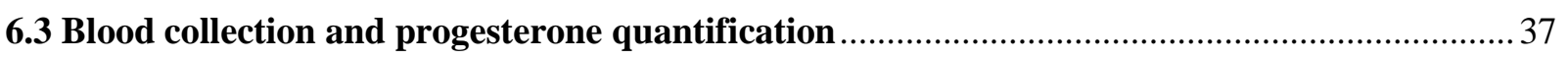

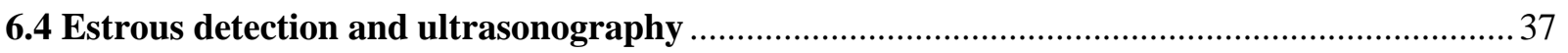


6.5 Breeding weight category, average daily gains category, and weight day average category ... 37

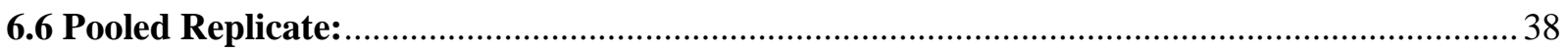

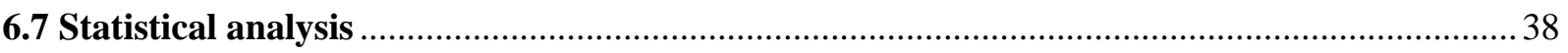

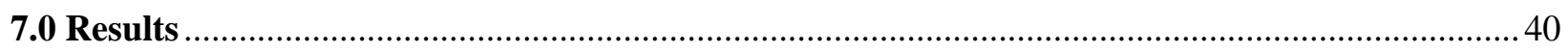

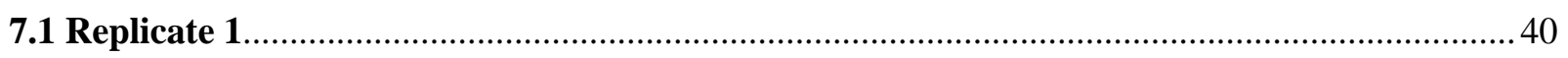

7.1.1 Breed, nutritional treatment, and progesterone pretreatment …............................................ 40

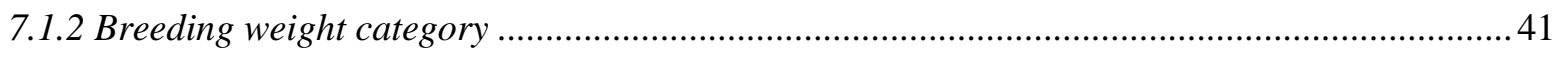

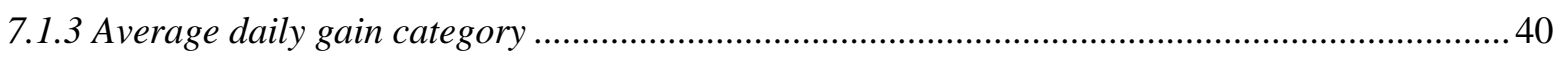

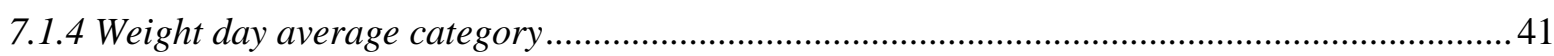

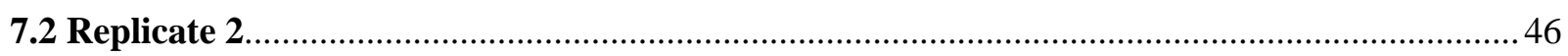

7.2.1 Nutritional treatment, and progesterone pretreatment …................................................... 46

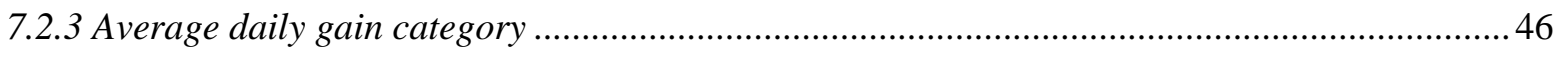

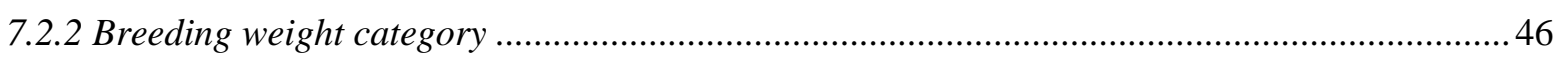

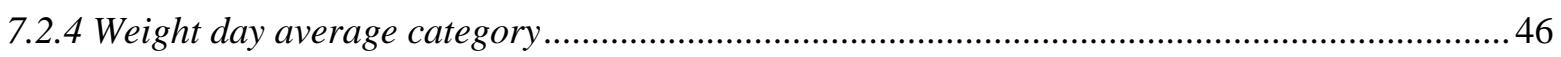

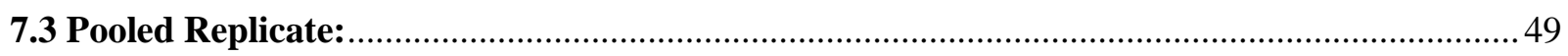

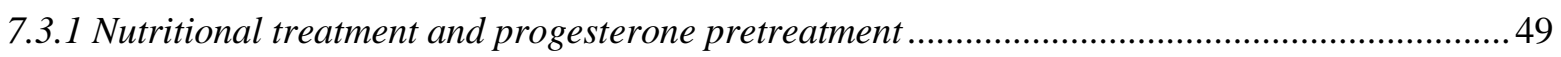

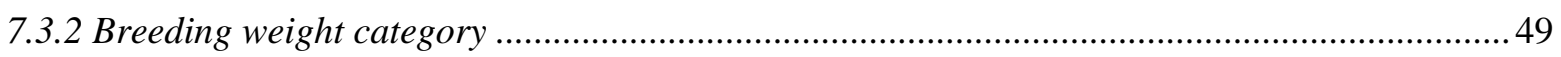

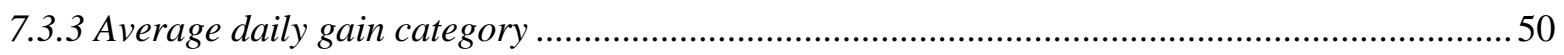

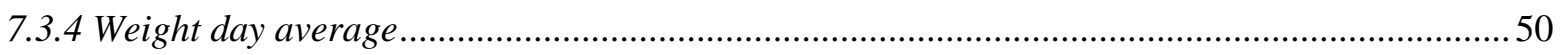

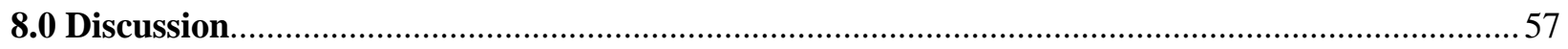

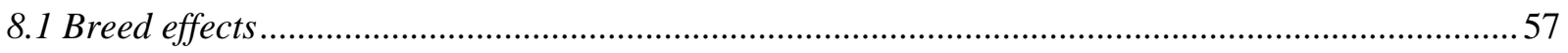

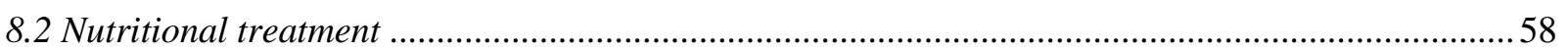

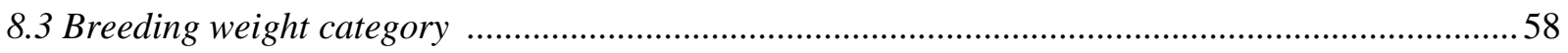

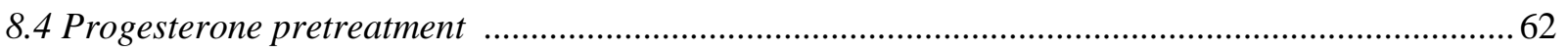

8.5 Average daily gains in the immediate pre-breeding period .......................................................... 62

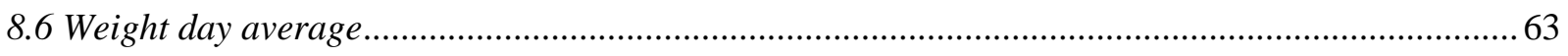

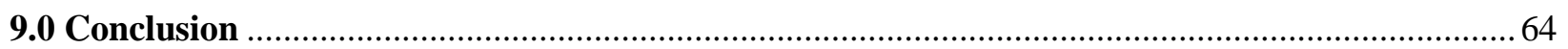

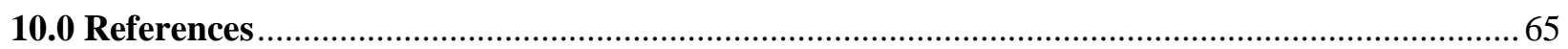

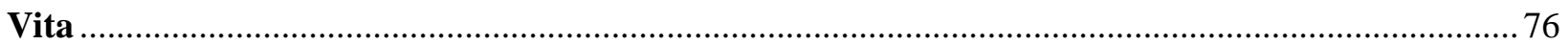




\subsection{Acknowledgements}

First and foremost, I want to thank my advisor and committee chair Dr. Marlon Knights for many hours of dedication, long road trips, knowledge, techniques within the animal science field, and life skills. He truly invests his time in the success of his students not just in academia, but to be well rounded individuals. Secondly, I want to thank my committee members Dr. Eugene Felton and Dr. Kevin Shaffer for their input on research, writing mechanics, and helping me to achieve my Master's degree.

I want to extend my sincerest gratitude to my past and present lab members: Dr. Adam Redhead, Ashleigh Nabers, Alana Cuiffi, Kyle Powell, Erin Greenleaf, and Abiodun Adebiyi. We have spent more hours than we want to admit traveling together for research trips and laughing along the way. They have become my extended family. Next, I want to thank Dr. Robert Goodman, Dr. Miroslav Valent and Gail Nesselrod Sager for help with numerous progesterone assays. I would also like to thank the sheep producers that have volunteered their time and ewe lambs for this research: George and Lisa Wherry of Wherry Farms, and Jerry Yates and Chestina Merriner of the WVU Reymann Memorial Research Farm.

Additionally, I want to thank my extended support system in West Virginia, across the United States, and internationally for believing in me, helping me through classes, motivating me in research, and supporting my community involvement.

Finally, this research was supported by the Northeast Sustainable Agriculture Research and Education (SARE) program and the Davis College of Agriculture, Natural Resources and Design, Division of Animal and Nutritional Sciences, West Virginia University. 


\subsection{List of Tables}

\subsection{Materials and Methods}

Table 1: Ewe lamb weight characteristics

\subsection{Replicate 1}

Table 2: Effect of breed, nutritional treatment, and progesterone pretreatment on growth and reproductive response of ewe lambs

Table 3: Effect of average daily gain (ADG) prior to breeding on reproductive response of ewe lambs

Table 4: Effect of weight at breeding on reproductive response of ewe lambs

Table 5: Effect of lifetime weight day average (LWDA) prior to breeding on reproductive response of ewe lambs

\subsection{Replicate 2}

Table 6: Effect of average daily gain (ADG) prior to breeding on reproductive response of ewe lambs

Table 7: Effect of lifetime weight day average (LWDA) prior to breeding on reproductive response of ewe lambs

\subsection{Pooled DT Replicate}

Table 8: Effect of nutritional treatment and progesterone pretreatment on growth and reproductive response of DT ewe lambs

Table 9: Effect of average daily gain (ADG) prior to breeding on reproductive response of DT ewe lambs

Table 10: Effect of weight at breeding on reproductive response of DT ewe lambs

Table 11: Effect of lifetime weight day average (LWDA) prior to breeding on reproductive response of DT ewe lambs

Table 12: Average breeding weight, ADG, and WDA for positive and negative reproductive outcomes in DT ewe lambs 


\subsection{Review of Literature}

\subsection{Introduction}

Replacement ewe lambs can compromise up to $20-30 \%$ of the breeding animals in sheep production providing an avenue to increase productivity within the flock; however, traditional breeding practices and decreased fertility hinder breeding replacement ewes to lamb at one year of age. Common practice is to breed replacement females as yearlings (16-20 months) allowing them to lamb initially at about two years of age. This practice is done to ensure that ewe lambs would achieve adequate weight and reproductive viability prior to breeding. However, breeding replacement females as ewe lambs (7-9 months) to lamb at one year of age can increase lifetime productivity while decreasing maintenance costs as a result of entering production earlier (Hulet et al, 1969; Jurgens et al, 2012; Kenyon et al, 2014). Additionally, reducing age at first lambing decreases generation interval facilitating faster genetic gains within the flock (Jurgens et al, 2012).

Ovulation, conception and fertility rates in ewe lambs are lower than mature ewes (Beck et al, 1996; Quirke and Hanrahan, 1977), and between $20-40 \%$ of ewe lambs exposed to rams do not lamb (Edey et al, 1978). This is likely the result of a short breeding period in ewe lambs. Kenyon et al (2014) noted that after reaching puberty, ewe lambs only experienced 2-3 estrous cycles before entering the anestrous period (Kenyon et al, 2014). Therefore, the pubertal transition is a limiting factor in breeding ewe lambs (Joubert, 1963).

Puberty is not solely a function of chronological age (Gaskins et al, 2005; Rosales Nieto et al, 2013a), but is characterized by the interaction between age, weight, and photoperiod (Foster et al, 1985). Once an animal grows past the inflection point on the growth curve, they will begin to deposit the excess energy as fat which is permissible for the pubertal transition. Average daily gains, breeding weight, body fat composition, and reproductive performance are positively 
correlated with reproductive outcomes (Rosales Nieto et al, 2013a). Regardless of breed, heavier females exhibit a higher probability of displaying estrous, becoming pregnant, pregnancy retention, and prolificacy (Corner-Thomas et al, 2015; Kenyon et al, 2006; Kenyon et al, 2009; Kenyon et al, 2010; Rosales Nieto et al, 2013b; Rosales Nieto et al, 2013a). Additionally, as noted by Corner-Thomas et al (2015) and Kenyon et al (2009), an increase in body fat composition increased overall fertility and lifetime productivity.

\subsection{Defining Puberty}

Puberty is the process of becoming mature enough to successfully reproduce (Bowstead, 1930). In females, this can be defined by three criteria: the age at first estrus, the age at first ovulation, and the age at which a female can competently support pregnancy. Outward signs of sexual receptivity define a female's age at first estrus, but the first estrus does not necessarily mark the time point in which puberty occurs but rather that puberty has been previously initiated. However, the male is necessary for the detection of estrus (Fabre-Nys and Gelez 2007; Fabre-Nys and Martin 1991a). First ovulation in ewe lambs does not coincide with visible estrus (Wettman 1980).

Therefore, tracking an animal's first ovulation is a better predictor of the onset of puberty but doing so requires frequent mapping of follicular growth to determine the exact timing of ovulation. Perhaps the most practical criterion of the occurrence of puberty is whether or not the female can successfully carry, deliver, and rear a neonate (Foster et al, 1985).

From an endocrine perspective, the peripubertal increase in GnRH secretion is permissive of ovulation and estrous cyclicity, in addition to the tonic center's basal level of low-amplitude low frequency secretions. The female's hypothalamic surge center, or medial preoptic area (POA), secretes gonadotropin releasing hormone $(\mathrm{GnRH})$ more frequently and in greater amounts. Enhanced secretion of GnRH stimulates increased secretion of gonadotropins luteinizing hormone 
(LH) and follicular stimulating hormone (FSH), which stimulates follicular development and secretion of estrogen resulting in ovulation (Foster et al, 1979; Foster et al, 1986; Ramirez and McCann, 1963).

Various factors such as age, environmental and social cues, genetics and nutrition influence the onset of puberty in ewe lambs. In conventional production systems, puberty is initiated during the fall when photoperiod is shortened and the ewe lamb has reached a threshold age and weight (Ebling and Foster, 1988). Most ewe lambs undergo puberty around 7 months of age once obtaining 40-60\% of their mature weight (Kenyon et al, 2014). If a ewe lamb does not reach puberty during the first breeding season, pubertal transition will be halted until the subsequent year (Foster et al, 1985; Foster et al 1986). Because sheep are short day seasonal breeders, estrous cyclicity is only initiated during times of decreasing photoperiod and temperatures (Ebling and Foster 1988).

\subsection{Endocrine Mechanisms of Puberty}

The ability to successfully reproduce is modulated by endocrine activity from the hypothalamus, anterior pituitary, ovaries, and uterus. Understanding the timing of endocrine activity associated with puberty is critical for developing synchronization protocols and efficiently managing reproduction. This can potentially decrease the generation interval for breeding animals and increase overall productivity.

\subsubsection{Timing}

The hypothalamus-pituitary-gonadal components that are necessary for puberty and cyclicity are set within a few weeks after birth (Fitzgerald and Butler, 1982; Foster et al, 1975; Huffman et al, 1987; Kennedy et al, 1974; Manning et al, 1993; Mansour, 1959). Prior to puberty, the hypothalamus exhibits an increased hyperreponsiveness to estradiol resulting in inhibition of 
GnRH and subsequent gonadotropin secretion and ovulation (Foster et al, 1986). Low doses of exogenous estradiol $(<1 \mathrm{pg} / \mathrm{ml}$ ) have been shown to reduce $\mathrm{LH}$ pulses by $50 \%$ within 24 hours after initial implant in an ovariectomized ewe lamb, while 1-2 pg/ml of exogenous estradiol will completely suppress LH pulses (Friedman et al, 1992).

As the developing female approaches puberty, the hypothalamic sensitivity to negative feedback by estradiol decreases, allowing for a steady increase in the amount of GnRH secreted (Foster et al, 1986), and an increase in the frequency of LH secretion by the anterior pituitary. In contrast to the pubertal ewe lamb, LH pulse frequency is much lower in the prepubertal ewe (Foster et al, 1979). Pulsatile secretions of LH began at about 11 weeks of age and puberty was reached at about 35 weeks of age in Shropshire and crossbred ewe lambs (Foster et al, 1975). In the same ewe lambs, systemic concentrations of FSH increased from 3-11 weeks, but did not change between 11 and 35 weeks (Foster et al, 1975). Foster et al (1986) used prepubertal ovariectomized ewe lambs chronically treated with estradiol to demonstrate the decreased sensitivity to estradiol inhibition. Prior to puberty, estradiol inhibited the release of LH via GnRH. However, around the typical age of puberty ( $\sim 30$ weeks), the same level of estradiol was unable to suppress LH secretion (Foster et al, 1986). Additionally, we lambs ovariectomized at three weeks of age demonstrated frequent LH secretion by six weeks of age further confirming estradiol as the factor inhibiting LH secretion during the prepubertal period (Foster et al, 1988).

However, it is important to note that estradiol does not act on GnRH neurons directly. Herbison et al (1993) showed that GnRH neurons do not contain estrogen receptor alpha (ER $\alpha$ ). More recently, Nestor et al (2012) demonstrated that estradiol acts directly on kisspeptin/ neurokinin B/ dynorphin (KNDy) neurons which communicate directly with GnRH neurons through close synapses. It has been shown that exogenous kisspeptin stimulates LH release in prepubertal females (Navarro et al 
2004; Kadokawa et al 2008; Lents et al 2008). Nestor et al (2012) further demonstrated that the number of kisspeptin-positive cells increase after puberty compared to the prepubertal period, and increase after ovariectomy in prepubertal ewe lambs providing evidence of the role of kisspeptin and neurokinin B during puberty in female sheep. Similarly, Redmond et al (2011a, 2011b) demonstrated that kisspeptin assumes a significant role in activation of the hypothalamus-pituitarygonadal axis in prepubertal ewe lambs. Kisspeptin stimulates LH release by acting through the hypophaseal portal system, and kisspeptin positively correlates with both age and LH secretion; whereas, the number of kisspeptin-positive cells increase with age (Redmond et al, 2011a; Redmond et al, 2011b).

Leptin is thought to play a permissive role in the attainment of puberty (Foster and Nagatani, 1999). The amount of leptin in blood is directly related to the amount of adipose tissue in the body (Ahren et al, 1997), and systemic concentrations of leptin increase with growth in prepubertal animals (Rosales Nieto et al, 2014). In the hypothalamus, leptin receptors have been localized in the supraoptic nucleus $(\mathrm{SON})$, paraventricular nucleus $(\mathrm{PVN})$, periventricular nucleus, arcuate nucleus, and lateral hypothalamus (Hakansson et al, 1998). However, GnRH neurons do not contain leptin receptors (Quennel et al, 2009). Rather, kisspeptin and the neuropeptide Y facilitate the communication between leptin and GnRH neurons. Kisspeptin neurons contain leptin recptors, and leptin treatment will increase the express of KiSS1 mRNA (Backholer et al, 2010; Luque et al, 2007). Additionally, hypothalamic neuropeptide Y exhibits an inhibitory effect on GnRH activity prior to sexual maturation (Klenke et al, 2010; Li et al, 1999), which decreases during the pubertal transition (Tillet et al, 2010). Furthermore, this was confirmed by delayed puberty onset when Neuropeptide Y was administered (Pierroz et al, 1995). In heifers, increased liveweight prior to puberty was associated with a decrease in neuropeptide Y expression (Allen et al, 2012; Alves et 
al, 2015), which has been shown to be associated with increasing levels of systemic leptin (Alves et al, 2015; Cardoso et al, 2014). Collectively, these data suggest that leptin is permissive to the pubertal transition by indicating adequate body weight and condition have been acieved.

\subsubsection{Hypothalamus}

The endocrine basis for the attainment of puberty is the ability of the hypothalamus to secrete high amplitude and frequent pulses of GnRH that trigger the preovulatory surge of LH and FSH. The hypothalamus is the final constituent to develop that regulates the onset of puberty, and subsequently allows for the pituitary, ovaries, and uterus to function at a mature level (Foster et al, 1975; Foster et al, 1986; Huffman et al, 1987; Manning et al, 1993). However, some studies suggest that the hypothalamus of the sheep has the ability to produce high-frequency GnRH pulses, and respond to estradiol stimulation prior to puberty.

The hypothalamus is sexually differentiated during embryogenesis which is necessary preparation for sexual development at puberty; however, the hypothalamus of both males and female embryos are similar in that they possess a tonic center and a surge center. In utero, testosterone production by the developing gonads passes through the blood brain barrier and is converted to estradiol via aromatase defeminizing the hypothalamus and rendering the surge center inactive in the male. In the female, estradiol secreted by the ovary is bound to alpha-fetoprotein and cannot pass the blood brain barrier allowing the surge center to remain functional (Bakker et al, 2006). The hypothalamic surge center must be fully developed before puberty because the surge center triggers the preovulatory surge of GnRH, which stimulates LH and FSH. The pattern of LH directly mimics that of GnRH secretion (Manning et al, 1993).

\subsubsection{Pituitary Gland}

The pituitary gland is developed and functional prior to puberty and does not impact the timing of sexual maturation. Luteinizing hormone (LH) and follicular stimulating hormone (FSH) are 
present in various amounts preceding the pubertal period, although LH frequency is mostly low and variable (Bindon and Turner, 1974; Echternkamp and Laster, 1976; Foster et al, 1975; Foster et al, 1975b; Huffman et al, 1987). During the week prior to first ovulation in the lamb, Huffman et al (1987) reported a fourfold increase in threshold LH (Huffman et al, 1987). Furthermore, LH amplitude increased with age and was great enough to produce ovulation by 12-20 weeks of age (Manning et al, 1993).

The role of FSH in the pubertal transition is poorly defined; however, by 10-12 weeks of age, systemic FSH levels in the ewe have risen to amounts comparable to mature ewes (Fitzgerald and Butler, 1982; Foster et al, 1975). This evidence indicates that the pubertal transition is limited at the level of the hypothalamus and secretion of adequate amounts and frequency of GnRH.

\subsubsection{Ovary}

\subsubsection{Prepubertal ovarian function}

Germ cells develop during embryogenesis and follicles are present prior to birth; however, they are not responsive to exogenous gonadotropins until 2-4 weeks of age once the granulosal and thecal layers are developed (Kennedy et al, 1974; Mansour, 1959). By 5-6 weeks of age, the ovary becomes responsive to exogenous gonadotropins simulating ovulation and formation of the corpus luteum (Worthington and Kennedy, 1979). The exogenous gonadotropins pregnant mare serum gonadotropin (PMSG) and human chorionic gonadotropin (hCG), have been shown to stimulate follicular growth and development which results in an increase in systemic estradiol activating the gonadotropin surge mechanism (Foster and Ryan, 1981).

In sexually immature sheep, administration of estradiol can induce an LH surge (Foster, 1984; Foster and Karsch, 1975; Foster and Olster, 1985; Keisler et al, 1985; Land et al, 1970; Squires et al, 1972;; Tran et al, 1979) by stimulating the release of GnRH to act on the anterior pituitary; 
however, developing sheep will return to an anovulatory state. Even though exogenous stimulation can induce ovulation and the formation of the CL, puberty and ovarian cyclicity will not be advanced. Prepubertal sheep did not exhibit multiple ovulations after the regression of the CL because the LH pulse frequency was not sustained (Foster et al 1984; Keisler et al, 1985).

\subsubsection{Progesterone priming}

Following initial ovulation, secretion of progesterone from the corpus luteum (CL) moderates the timing of the estrous cycle through controlling prostaglandin $\mathrm{F}_{2 \alpha}\left(\mathrm{PGF}_{2 \alpha}\right)$. In pubertal and seasonally anestrous females, the first ovulation occurs without estrus and is followed by a shortened luteal phase before initiating or resuming normal cyclicity. After ovulation and formation of the $\mathrm{CL}$ in females that exhibited a short luteal phase, a premature surge of $\mathrm{PGF}_{2 \alpha}$ lysed the CL in sheep, goats, and cattle (Menchaca and Rubianes, 2001; Zollers et al, 1993), which is directly related to the number of progesterone receptors in the uterus. In cows, Zollers et al (1993) demonstrated that the endometrium of the uterus of a female experiencing a short cycle possessed significantly less progesterone receptors than a progesterone pretreated female with a

normal cycle. In sheep, preovulatory estradiol from growing follicles induced the synthesis of progesterone receptors, and the amount of estradiol secreted was directly related to the number of progesterone receptors on the uterine endometrium (Xiao and Goff, 1999; Zelinski et al, 1980).

LH pulses remain low before the initial ovulation in peripubertal or anovulatory females. In turn, low levels of estradiol are secreted, and the synthesis of endometrial progesterone receptors is decreased. Additionally, up-regulation of the progesterone receptors and the delayed secretion of $\mathrm{PGF}_{2 \alpha}$ require the exposure of the uterus to progesterone and the subsequent preovulatory rise in estrogen (Kieborz-Loos et al, 2003). 
In beef cattle, pretreatment with progestogen resulted in a CL with a normal lifespan (RamirezGodinez et al, 1981; Ramirez-Godinez et al, 1982), which increased fertility in postpartum cows by preventing the shortened luteal phase (Ramirez-Godinez et al, 1981). Further research indicates that levels of $\mathrm{PGF}_{2 \alpha}$ from the uterus increase steadily during the time of progesterone pretreatment (Cooper et al, 1991); however, progesterone pretreatment is necessary to prevent premature secretion of $\mathrm{PGF}_{2 \alpha}$, surpassing the shortened luteal phase. Ovulation followed by the shortened luteal phase prevents the occurrence of a fertile mating during the transition from seasonal anestrus or the pubertal transition. 


\subsection{Factors Affecting Puberty}

Various factors affect the attainment of puberty and the fertility of ewe lambs. Such factors include age, seasonality, nutrition, liveweight, body composition, presence of a male and teasing.

\subsubsection{Age}

A threshold age must be obtained for females to initiate the pubertal transition; however, chronological age cannot be determined as a function of puberty due to the confounded effects of age, weight, and body composition (Corner-Thomas et al, 2015; Kenyon et al, 2009; Kenyon et al, 2010; Villa-Godoy et al, 1990).

Levine et al (1978) reported that animals bred within their first year of life have an increase in productivity within their initial three years of production. In contrast, Saoud and Hohenboken (1984) reported is no correlation between age at first estrus and reproductive performance within the first 4-5 years of production when the ewe lambs were bred to lamb at about one year of age. Although reports are conflicting, it is logical that breeding replacement females as ewe lambs rather than yearlings will increase their overall productivity regardless of age when bred during the first breeding season.

\subsubsection{Seasonality}

Sheep are short-day seasonal breeders, meaning that the onset of estrus is stimulated in the fall when photoperiod and temperature decrease (Ebling and Foster 1988). Seasonal polyestrous cycles of sheep occur in autumn and significant variation in length of estrous activity exists among breeds (Foster et al, 1986). Merino breeds have estrous cycles for 200-260 days while black face breeds have estrous cycles for 100-140 days, before anestrus during the spring and summer months (Foster et al, 1986). This allows sheep to undergo parturition in the spring when conditions are ideal for supporting lactation and neonatal growth. 
Melatonin from the pineal gland stimulates the hypothalamus via optic stimuli traveling through the central nervous system. During autumn when sheep perceive a decrease in photoperiod, melatonin secretion increases (Yellon and Foster, 1986) down regulating the inhibitory action of RFRP-3 on kisspeptin neurons (Clarke et al, 2008; Smith et al, 2008), and allowing an increase in GnRH pulse frequency and amplitude which stimulates the LH surge and ovulation.

Given adequate nutrition, lambs born in spring will reach puberty in the subsequent fall. In contrast, fall-born ewe lambs will not reach puberty until 10-12 months of age in the next fall (Foster et al, 1986). Irrespective of photoperiod, ewe lambs that have not reached adequate body weight and composition will not undergo the pubertal transition as the development of hypothalamic neurons and their ability to positively respond to stimuli can be impacted by threshold body size and fat composition.

Menassol et al (2012) investigated the interaction between photoperiod and nutrition as it relates to seasonality in the ewe and reported that nutritional status modulates the interpretation of photoperiod stimulating reproduction. Ile-de-France ewes were maintained as well-fed or feed restricted for two complete years. In the second year, half of each group were ovariectomized and fitted with an estrogen implant. Well-fed females had an increase in the duration of ovarian activity (Year 1: $133 \pm 5 \vee 63 \pm 12$ and Year 2: $176 \pm 13 \vee 81 \pm 21$ days) due to the fact that restricted females experienced the onset of estrus later and estrous cycles ceased earlier in the breeding season. The time at which ovarian activity was initiated was negatively correlated with body condition (Year 1: $r=-0.69$ and Year 2: $r=-0.73$ ); whereas, ovarian activity started earlier with each incremental increase in body condition. Additionally, the end timing of estrous activity was positively correlated with body condition (Year 1: $r=0.42$, and Year 2: $r=0.74$ ). With each subsequent increase in body condition score, the timing of transition into the anestrous period was 
delayed. During breeding season, serum concentrations of LH remain high (>1 ng/ml) for longer periods in well fed OVX ewes ( $188 \pm 10$ v $132 \pm 3$ days), and the same correlations with BCS were observed with LH for the beginning $(r=-0.62)$ and end $(r=0.71)$ of the neuroendocrine activity (Menassol et al, 2012). Hence, adequate nutritional management is necessary to maximize the length of the breeding season in seasonally polyestrous breeders.

\subsubsection{Nutrition}

Nutrition has the greatest potential to affect puberty onset and subsequent productivity of ewe lambs. The Critical Body Weight Hypothesis describes the phenomenon that heavier females reach puberty at a younger age (Frisch and McArthur, 1974); however, body weight alone is not the best predictor of puberty. Body condition and fat composition more adequately relate to the process of becoming sexually mature.

Nutritional management affects daily gains and has the potential to advance the onset of puberty (Villa-Godoy et al, 1990). In a situation with limited nutritional availability, nonessential processes such as reproduction will cease. With regards to nulliparous animals in a limited nutrition environment, reproductive function would not be initiated due to available nutrients being repartitioned from fat storage and reproduction to supporting physiological processes required for maintenance (Bizelis et al, 1990; Boulanouar et al, 1995; Burfening and Bererdinelli, 1986). Regardless of species, the goal of nutritional management of replacement females is to not delay puberty or reproductive maturity, to reach adequate live weight and composition at breeding, and to maintain acceptable growth during gestation to result in easy parturition (Bearden et al, 2004).

Conventionally, it is recommended to feed ewe lambs $1-1.5$ pounds $(0.45-0.68 \mathrm{~kg})$ per day of grain plus pasture or hay through the natural breeding season of fall and winter to ensure nutrient demands are met (Jurgens et al, 2012). Replacement ewe lambs are typically fed a lamb finishing 
diet until 90-120 days of age (ranging between 36-41 kg; Jurgens et al, 2012). In heifers, feeding a high energy diet (liveweight gain $0.9 \mathrm{~kg} /$ day) compared to a low energy diet (liveweight gain of $0.3 \mathrm{~kg} /$ day) from 8 months of age allows the female to obtain puberty at an earlier age and have a preovulatory follicle $(13 \mathrm{~mm})$ present at a younger age $(372 \pm 0.7 \mathrm{v} 435 \pm 0.9$ days; Bergfeld et al, 1994). A high energy diet also increased the frequency of LH pulses to simulate follicular growth and ovulation at an earlier age. Whereas, the LH pulses are not stimulated to the same degree in the heifers supplemented with a lower energy diet, thus resulting in delayed puberty (Day et al, 1986).

An elevated post-weaning plane of nutrition has been shown to increase average daily gains (ADG), breeding weight, ovulation rate, estrous response, prolificacy, and overall fertility compared to ewe lambs on a restricted diet (Bizelis et al, 1990; Burfening and Bererdinelli, 1986). Bizelis et al (1990) split Chios and Karagouniki ewe lambs ( $85 \pm 1$ day of age) into two treatment groups: high versus low plane of nutrition. The high plane of nutrition group was supplemented feed to achieve weight gain of $100 \mathrm{~g} / \mathrm{day}$ and to reach $70 \%$ mature weight at breeding. The low plane of nutrition group was supplemented to gain $50 \mathrm{~g} /$ day and reach $50 \%$ mature weight at breeding. The high treatment group grew more rapidly and were $12.5 \mathrm{~kg}$ heavier at breeding. In addition, the females in the high plane of nutrition treatment group had a significantly increased ovulation rate $(1.51 \pm 0.08 \mathrm{v} 1.15 \pm 0.08)$, and tended to display estrus at a younger age ( $322 \mathrm{v} 327$ days). In a subsequent breeding season, carryover effects related to ovulation rates were observed where the high treatment group maintained a higher ovulation rate during the second year (1.94 \pm 0.10 v 1.72 \pm 0.11 ; Bizelis et al, 1990). Additionally, Burfening and Berardinelli (1986) fed ewe lambs (5-6 months of age) either a high energy or a low energy diet for three months prior to 
breeding and reported that a greater percentage of ewe lambs on the high energy diet lambed $(23.4 \pm 2.3$ v $17.1 \pm 2.4)$.

Restricting dietary protein or energy delays the onset of puberty but not the weight at which puberty is initiated. Ewe lambs averaging $22.1 \pm 1.9 \mathrm{~kg}$ and $106 \pm 1.3$ days in experiment one and $35.5 \pm 0.6 \mathrm{~kg}$ and $131 \pm 1.5$ days were assigned to be fed a control (18 MJ ME day-1 and $173 \mathrm{~g}$ MP day-1), restricted protein (PR: 11 MJ ME day-1 and 66 g MP day-1), or restricted energy diet (ER: 10.2 MJ ME day-1 and $96 \mathrm{~g}$ MP day-1). Ewe lambs fed the control diet gained more weight

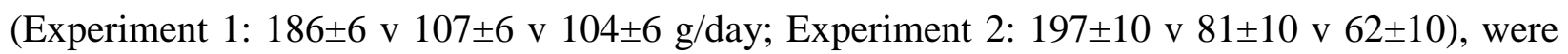
heavier at puberty (Experiment 1: $35.3 \pm 1 \mathrm{v} 31.5 \pm 1 \mathrm{v} 30.3 \pm 1 \mathrm{~kg}$; Experiment 2: $46.8 \pm 1.4 \mathrm{v}$ $44.3 \pm 1.4 \mathrm{v} 44.1 \pm 1.4 \mathrm{~kg}$ ), and reached puberty at an earlier age (Experiment 1: $169 \pm 5.2 \mathrm{v} 178 \pm 5.2$ v 186 \pm 5.2 days; Experiment 2: $205 \pm 5$ v $242 \pm 5$ v $259 \pm 5$ days) compared to both the restricted protein and restricted energy dietary treatment groups (Boulanouar et al, 1995). At puberty, restricted groups from experiment 1 were similar in age $(186 \pm 5.2 \mathrm{v} 178 \pm 5.2$ days). Furthermore, groups that switched from a restricted diet to the control diet showed significant differences in body weight (PR: $33.6 \pm 1$ v $31.5 \pm 1 \mathrm{~kg}$; ER: $32.6 \pm 1$ v $30.6 \pm 1 \mathrm{~kg}$ ) and weight gained (PR: $177 \pm 6 \mathrm{v}$ $104 \pm 6$ g/day; ER: $155 \pm 6$ v $107 \pm 6$ g/day) but did not reach puberty any earlier than lambs fed the restricted diet alone (PR: $179 \pm 5.2$ v 178 \pm 5.2 days; ER: $181 \pm 5.2$ v 186 \pm 5.2 days; Boulanouar et al, 1995). Feeding a diet that meets the energy and protein requirements of replacement ewe lambs is necessary to not delay reproductive maturity. Restricting either dietary protein or energy will delay the onset of puberty to a later age, because it takes longer for the animals to reach the required weight range, composition, amount of adipose tissue, and systemic leptin permissive to the preovulatory surge of gonadotropins. 


\subsubsection{Liveweight and Body Composition}

When ewe lambs fed to achieve a positive energy balance, fat deposition occurs enabling the initiation of puberty. Given that she has reached the threshold age, excess internal energy gets converted into fat stores and the animal begins to prioritize reproduction. Feed restriction can suppress the estrous cycle and reproductive behavior when fat deposits are not available to cover demands (Bronson, 2000; Schneider and Wade, 2000). There is an extended response to negative feedback of estrogen in ewe lambs that lack sufficient dietary energy in the prepubertal period (Foster et al, 1986). In this case, there is not enough blood glucose and fatty acids, nor enough adipose tissue to release leptin to permit pubertal onset. Serum leptin is positively correlated with the amount of body fat stores and is key in signaling the hypothalamus to initiate puberty. Increasing amounts of circulating letpin is permissive of puberty. In mice, exogenous leptin can overcome the delay or puberty observed in feed restricted animals that have not had adequate nutrition to achieve a positive energy balance (Cheung et al, 1997). Additionally, exogenous leptin has been shown to be a trigger puberty in leptin deficient (ob/ob) mice (Chehab et al, 1997), and systemic concentrations of leptin increase with growth as premature animals approach puberty (Foster and Nagatani, 1999; Rosales Nieto et al, 2014). Cardoso et al (2014) showed the relationship between increased body weight gain and puberty in Angus X heifers as it relates to changes in systemic leptin. At 3.5 months of age, heifers were weaned and allocated to either the high gain $(1.0 \mathrm{~kg} / \mathrm{day})$ or low gain $(0.5 \mathrm{~kg} / \mathrm{day})$ treatment groups. During the treatment period, blood was collected twice a month to determine serum leptin concentrations and starting at 7.5 months, blood samples were collected two times each week for progesterone quantification. At 8 months of age, LH pulse frequency was greater in the high gain versus the low gain group, and at nine months of age, the proportion of pubertal heifers was greater in the high gain group. Serum concentrations of leptin were greater in the high treatment group at six months of age and remained 
higher for the entirety of the experiment (Cardoso et al, 2014). Next, Samadi et al (2014) studied the effects of supplementing an increased plane of nutrition compared to a moderate plane on nutrition on body weight, body condition, and circulating concentrations of leptin in heifers. Leptin was elevated from 11-23 months of age in the increased nutritional treatment group compared to the moderate nutritional group $(0.98 \pm 0.03 \vee 0.75 \pm 0.02 \mathrm{ng} / \mathrm{ml})$, and this was coupled with heavier body weights and increased body condition scores during this time period.

In addition to leptin, follistatin is thought to be related to body composition and reproduction which is an indicator of the level of muscling. Follistatin is secreted by muscle cells in addition to a variety of other cells and is important for growth and development. Unlike leptin, follistatin appears to have no effect on GnRH secretion in sheep (Padmanabhan et al, 2002), though it is known to act on the pituitary to inhibit FSH secretion in rodents (Ueno et al, 1987). Additionally, follistatin acts on ovarian function in mice. Deletion of follistatin from granulosa cells decrease fertility, decreases litter size, and terminates ovarian activity in mice (Jorgez et al, 2004; Kimura et al, 2010). Rosales Nieto et al (2014) studied the relationships of serum leptin and follistatin to fat and muscle accumulation in pubertal sheep. Circulating leptin is positively correlated with phenotypic values for eye muscle depth, fat, liveweight, post-weaning eye muscle depth, postweaning fat, and post-weaning liveweight. Follistatin was negatively correlated with eye muscle depth and live weight, post-weaning eye muscle depth, and fat. Furthermore, leptin was positively associated with liveweight at first estrus, but negatively associated with age. Leptin was positively associated with fertility and reproductive rate. However, follistatin was negatively correlated to liveweight at first estrus, fertility, and reproductive rate suggesting an inhibitory role in the pubertal transition (Rosales Nieto et al, 2014). 
Regardless of breed, heavier females have a higher probability of becoming pregnant, retaining their pregnancy, and having multiple births (Kenyon et al, 2006; Rosales Nieto et al, 2013b). Research by Rosales Nieto et al (2013b) reported on the positive correlation between average daily gain, breeding weight, body composition, and reproductive performance in Merino ewe lambs. Ewe lambs were more likely to achieve puberty by 251 days if they had higher values for post weaning liveweight, eye muscle depth, and fat. For this study, the average age at first estrus was $197 \pm 2$ days, and the average weight was $41.1 \pm 0.4 \mathrm{~kg}$ ( $67 \%$ of mature weight for the Merino breed: $61.6 \pm 0.4 \mathrm{~kg}$ ). Additionally, the proportion of ewe lambs that exhibited an estrous response increased by $4 \%$ with each 20g increase in ADG (Rosales Nieto et al, 2013b). The research of Kenyon et al (2006) support these findings showing that heavier ( $42.1 \mathrm{v} 40.8 \mathrm{~kg}$ ) ewe lambs are more likely to be mated in the first 17 days after ram introduction $(39.0 \mathrm{v} 37.0 \mathrm{~kg})$, and more likely to be twin-bearing rather than singleton $(39.8$ v $38.0 \mathrm{~kg}$; Kenyon et al, 2006). Hence, it is imperative to have a proper nutritional plan to get the replacement ewe lambs to an optimal weight before breeding season.

In dairy heifers, the interaction between age and weight relative to puberty were investigated. Heifers fed a high plane of nutrition ( $\mathrm{ADG}=2.0 \mathrm{lbs} /$ day) for one year reached puberty earlier (6-8 months) than those supplemented a moderate or low plane of nutrition. The moderate nutritional plane ( $\mathrm{ADG}=1.5 \mathrm{lbs}$ ) displayed estrus between 9 and 11 months while the restricted feed group ( $\mathrm{ADG}=1.2 \mathrm{lbs}$ ) reached puberty by 12 months; however, their size was too small to undergo pregnancy and parturition without complication (Villa-Godoy et al, 1990).

Nutrition is the producer's greatest control over the generation interval of the flock (Bearden et al, 2004). Plane of nutrition is directly correlated with body composition in terms of muscling and adiposity. In turn, ewe lambs with a greater body composition have an increase in fertility and 
lifetime productivity. Ewe lambs marked in the first 17 days of breeding were heavier at breeding and had a greater BCS $(42 \pm 0.20$ v $39.9 \pm 0.44$ and $38.7 \pm 0.68 \mathrm{~kg} ; 2.4 \pm 0.02$ v $2.3 \pm 0.05$ and $2.2 \pm 0.7)$ than ewe lambs marked in the second 17 days of the breeding period or not marked during 34 day breeding period, respectively (Kenyon et al, 2009). In a subsequent study, Kenyon et al (2010) observed the same estrous response; whereas, heavier ewe lambs displayed estrous earlier than lighter weight ewe lambs. Additional findings prove that ewe lambs with a BCS of 2.5 or greater were more likely to be bred in the first 17 days of the breeding period compared to ewe lambs with a body condition of 2.0 or 1.5 . Throughout the 34 day breeding period, as body condition score increased, there was an increase in pregnancy rates (BCS $1.5=63.7 \%$ v BCS $2.0=76 \%$ v BCS $2.5=83 \%$; Kenyon et al, 2010).

Consequently, there is a threshold weight and BCS in which achieving greater gains and condition prior to breeding will not have increasing effects. Corner-Thomas et al (2015) analyzed the relationships between pre-breeding liveweights and BCS on fertility and reproductive rates in crossbred ewe lambs consisting of Romney crossed with Texel, Finnish Landrace, and Coopworth. Fertility was determined as the number of ewe lambs that were pregnant and reproductive rates were determined as the number of fetuses per 100 ewes that were bred. The results showed that fertility rates (conception rates) increased synonymously with livewights until $47.4 \mathrm{~kg}$ of weight, and reproductive rates were highest between 47.5 and $52.2 \mathrm{~kg}(138 \%)$. Additionally, $90 \%$ fertility was achieved at the threshold BCS of 3.5, and reproductive rates peaked at $130 \%$ with a body condition of 3.0. Given the previous, an increased pre-breeding plane of nutrition increases reproductive outcomes in ewe lambs due to increasing live weights and body composition that are permissive for puberty and fertility responses. 


\subsubsection{Exogenous Progesterone}

Conventionally, exogenous natural progesterone mimics that of the luteal phase of the estrous cycle (Abecia et al, 2012), allowing for the manipulation of the circulating progesterone levels to time the onset of estrus and ovulation (Hansel and Convey, 1983). During the breeding season, removal of exogenous progesterone initiates a cascade of increasing $\mathrm{GnRH}$ to increase gonadotropin release. Release of gonadotropins stimulates follicles to grow and release increasing amounts of estrogen to trigger the preovulatory surge of $\mathrm{GnRH}$ and $\mathrm{LH}$ that stimulate ovulation (Barrell et al, 1992; Goodman, 1994).

Pretreating with progesterone increased the sensitivity of the hypothalamus to estradiol (FabreNys and Martin, 1991b; Robinson, 1955), and prevented the short cycle after ram introduction (Congnie et al, 1982; McLeod and Haresign, 1984; Pearce and Robinson, 1985). Protocols utilizing progesterone during breeding have shown to increase pregnancy rates to the first service by $30 \%$ in pubertal ewe lambs (Sawalhah et al, 2011; Stellflug et al, 2001) and have the ability to hasten the onset of puberty in heifers (Hall et al, 1997). Crossbred beef heifers were split into three different age classifications $(9.5,11$, and 12.5 months) and half of each group were synchronized using a 10 day implant of Norgestomet (6mg; synthetic progesterone homologue). In the 12.5 month age classification, more progestin pretreated heifers displayed pubertal estrus in the first 5 days following removal compared to the control heifers $(82 \mathrm{v} 9 \%)$. This same result was not observed in the 9.5 or 11 month age groups (progestin x age). Additionally, progestin pretreatment increased the LH pulse frequency in all age classifications, and increased the mean LH concentration in the 12.5 group alone (progestin $\mathrm{x}$ age). Finally, progestin pretreatment positively influenced follicular characteristics within the ovaries at the time of implant removal; whereas pretreated females increased the number of follicles with a diameter greater than $8 \mathrm{~mm}$, and increased the size of the largest follicle (Hall et al, 1997). 
The ability of progesterone priming to promote the pubertal transition has been further demonstrated in sheep. In seasonally anestrous ewe lambs bred in July (251 days), only lambs that received a progesterone pretreatment (used CIDR device) expressed estrus (Knights et al, 2002), consistent with the requirement of a period of progesterone priming for the induction of estrus at ram introduction (Knights et al, 2001).

\subsubsection{Presence of a Male and Teasing}

The ram effect is driven primarily by pheromones, and studies have shown that these olfactory cues have the ability to regulate puberty (Knights et al, 2002; Kenyon et al, 2012). The odors and socio-sexual behaviors of the ram activates the main olfactory bulb and the accessory olfactory system to communicate via the amygdala and associated cortices. Signals are sent to kisspeptin neurons in the medial preoptic area of the hypothalamus to simulate GnRH secretion. GnRH activates the release of LH from the anterior pituitary (Fabre-Nys et al, 2015).

Introduction of the male advances the onset of puberty (Ungerfeld et al, 2004) by stimulating an increase in mean LH and LH pulse frequency that simulates follicular development and subsequently ovulation (Knights et al, 2002). Knights et al (2002) assigned mixed breed fall-born ewe lambs $(41.8 \pm 0.6 \mathrm{~kg}$, and $250.7 \pm 1.3$ days of age $)$ to one of five treatment groups: 1$)$ the control that received no additional treatment, 2) a group to only be introduced to rams, 3) a group to be treated with only progesterone via a CIDR, 4) a group that was both treated with progesterone and exposed to the ram at CIDR removal, and 5) a group that was progesterone pretreated, exposed to the ram at CIDR removal, and received an injection of estradiol benzoate $\left(25 \mu \mathrm{g} \mathrm{E}_{2} \beta\right)$. More ewe lambs exposed to rams exhibited an LH surge compared to those that did not have ram introduction (control: $0 \%$, trt 2: $100 \%$, trt 3: $0 \%$, trt 4: $72.7 \%$, and trt 5: 100\%). Additionally, ewe lambs exposed to rams displayed a higher LH pulse frequency (pulses/8h, $7.7 \pm 0.5 \mathrm{v} 2.7 \pm 0.8$ ) than those 
that were not introduced to a ram (Knights et al, 2002). Kenyon et al (2012) demonstrated a similar response in a consecutive two year study. More ewe lambs achieved puberty when exposed to vasectomized rams for 17 days compared to control females not exposed (48 v $24 \%$ and 80 v $18 \%$; Kenyon et al, 2012). However, it must be noted that puberty cannot be accelerated via exogenous hormones or the ram effect in animals that have not achieved adequate age, liveweight, or body condition for the hypothalamus to respond positively to estradiol.

The use of a teaser ram also positively enhances fertility response in ewe lambs. The use of a teaser has been shown to advance the number of females mated during the first 17 days of breeding (62.6 v 32.1\%) and increase the overall pregnancy rate (88.8 v 82.2\%; Kenyon et al, 2006). Additionally, ewe lambs exposed to vasectomized rams exhibited a higher conception rate to the first 17 days (18.2 v 6.8\%; 27 v 17\%; Cave et al, 2012). Exposure to vasectomized rams through either direct contact or fence line contact during the peripubertal period increased the proportion of ewe lambs that initiated estrous cyclicity prior to breeding compared to ewe lambs that did not have contact with vasectomized rams (40.0 \pm 4.8 and $31.7 \pm 4.8$ v $8.8 \pm 4.8$, respectively; Hudgens et al, 1987). The exposure of ewe lambs to rams increased the growth rate of the largest follicle (between 0 and 36 hours), increased the diameter of the largest follicle at 36 hours, and increased ovulation rate compared to control animals, as well as animals treated with progesterone or estrogen (Knights et al, 2002). This increase in follicle diameter has been reported on day $9(6.9 \pm 0.4 \mathrm{v} 5.8 \pm 0.4 \mathrm{~mm})$ and day $12(7.1 \pm 0.4$ v 5.4 $\pm 0.4 \mathrm{~mm})$ in the Romney breed (Kenyon et al, 2012).

Furthermore, the length of time of teasing has an effect on fertility. In studying the effects of teasing for 17 days or 8 days before breeding, Kenyon et al (2006) found that teasing for 8 days would increase the estrous response $(88.6 \mathrm{v} 75.1 \%)$ but not the pregnancy rates during the first 17 days period (61.4 v 58.0\%). However, teasing for 17 days increased both the estrous response 
$(92.3 \mathrm{v} 75.1 \%)$ and the pregnancy rate $(70.7 \mathrm{v} 58.0 \%)$ to the first 17 day period when compared to the unteased ewe lambs. Additionally, ewe lambs teased for 17 days are more likely to be twin bearing rather than singleton compared to unteased or ewe lambs teased for 8 days (Kenyon et al, 2006). 


\subsection{Ewe Lamb Fertility}

Overall fertility is significantly reduced in ewe lambs compared to mature ewes. To understand the mechanisms behind this reduced fertility, it is important to first understand fertility in mature animals. As previously discussed, sheep are seasonally polyestrous breeders meaning that they initiate cyclicity in the fall and undergo seasonal anestrus in the spring and summer months. The length of time a female cycles varies by breed. Merino breeds cycle for 200-260 days allowing for 11-15 breeding opportunities during the season. Black face breeds cycle for 100-140 days giving only 6-8 opportunities for successful breeding. Furthermore, ovulation rates vary significantly; whereas, highly prolific breeds such as the Barbados black belly and polypay breeds can ovulate multiple ova during one cycle compared to less prolific females such as the Columbia breed.

Although, heritability of reproductive traits is low (Safari et al, 2007). Heritability for lamb survival and litter size are estimated to be 0.3 0.19, respectively (Afolayan et al, 2008). Additionally, Fogarty et al (1994) heritability of number of lambs born and the number of lambs weaned as 0.17 and 0.08 , respectively. Therefore, it is believed that epigenetic factors and management practices modulate the decreased fertility in ewe lambs.

A thorough understanding of gestation in sheep is necessary to understand the mechanisms for decreased fertility in ewe lambs compared to mature ewes. After ovulation, spermatozoa will connect with the ovum in the ampullary-isthmic junction of the oviduct where fertilization will occur. Initially, a single celled zygote with two pronuclei will form, and within 24 hours the cell will begin to undergo division. About day 3-4, the embryo will enter the morula stage where individual cells can no longer be distinguished. Within days 4-10 differentiation will begin and a blastocyst will form with an inner cell mass that will become the fetus, a blastocoele cavity, and trophoblast cells. Additionally, within this time period the blastocyst will hatch out of the zona 
pellucida and prepare for implantation. Implantation will occur about day 16. Gestation in sheep lasts 145-150 days.

Post fertilization day 12-15, trophoblast cells from the blastocyst signal the ewe's pregnancy via the action of interferon-tau (INF- $\tau$ ) inhibiting the release of PGF2 $\alpha$ prolonging the life of the CL (Bazer et al, 1989). This paracrine action is dependent on the presence of progesterone receptors on the uterine endometrium (Ott et al, 1992).

Progesterone is the primary hormone for the maintenance of pregnancy during gestation. Throughout pregnancy, plasma progesterone increases gradually during the first 90 days of gestation and then peaks at day 125 prior to falling before parturition (Bassett et al, 1969); however, the source of progesterone changes during this time period. In the first third of the pregnancy, progesterone is secreted form the CL in high enough quantities to prevent cyclicity and prepare the uterus for implantation. Around day 50, the placenta is secreting progesterone in high enough quantities to maintain pregnancy and the CL regresses (Casida and Warwick, 1945).

\subsubsection{Ovulation Rates}

Ewe lambs experience a decrease in overall fertility attributed to lower ovulation rates and higher embryonic mortality rates compared to mature ewes. Ewe lambs have a lower ovulation rate compared to mature ewes as demonstrated in Romney and Romney cross (1.14 v 1.82 and $1.44 \mathrm{v}$ 1.84; Mulvaney et al, 2013) Clun forest (1.07 v 1.25; Beck et al, 1996), and Galway (1.51 v 3.07) breeds (Quirke and Hanrahan, 1977). Additionally, lowland Clun Forest ewes experience a subsequent increase in ovulation rate as they increase in age (ewe lambs $=1.15 \mathrm{v}$ yearlings $=1.55$ $\mathrm{v}$ two year olds=1.75; Forrest and Bichard, 1974).

When analyzing the ovulation rate within each individual ewe lamb, the ovulation rate does not change between cycles in the first breeding season following puberty. However, there are fewer 
viable embryos that result from mating the first cycle versus the second or third (Hare and Bryant, 1985).

\subsubsection{Conception and Pregnancy}

Pregnancy rates in ewe lambs are lower than yearlings and mature ewes (56 v $93 \mathrm{v} 95 \%)$ as demonstrated in Clun Forest lowland sheep (Forrest and Bichard, 1974), and a significant decrease in pregnancy rate for ewe lambs compared to mature ewe has been demonstrated in a composite breed (1/2 Romney, 1/4 Texel, 1/4 Finn; 7 v 86\%; Mulvaney et al, 2013).

During the first two months after conception, progesterone is supplied from the corpora lutea (CL; Wilmut et al, 1995), and is essential for maintaining pregnancy. Lower serum progesterone has been observed in ewe lambs compared to mature ewes between 14 and 30 days of gestation (Davies and Beck, 1993) and has been related to increased incidence of embryonic loss. In contrast, administering hCG (100 IU) or progesterone $(12 \mathrm{mg})$ to ewe lambs did not affect blastocyst development (Nephew et al, 1994); however, administering a higher dosage of hCG (150 IU) at mating increased embryo viability in the ewe lamb by increasing the crown-rump length $(12.7 \mathrm{~mm}$ v $11.9 \mathrm{~mm})$, the amniotic sac width $(12.0 \mathrm{~mm} \vee 11.4 \mathrm{~mm})$, and the number of placental placentomes (122.4 v 90.8) compared to the control group (Khan et al, 2003). These findings lead to the suggestion that administering hCG at mating can increase embryonic development and overall fertility of ewe lambs. Research demonstrates that injecting $200 \mathrm{IU}$ of hCG 12 days post mating did not improve lambing outcome compared to the control (41 v 48\%; Khan et al, 2009). Therefore, the timing and dosage of administration are critical.

Quirke and Hanrahan (1977) observed that Galway ewe lambs have a high ovum cleavage rate $(80 \%)$ but a low implantation rate $(<40 \%)$, and ova from ewe lambs have a lower capacity for 
survival compared to mature ewes (Quirke and Hanrahan, 1977). In addition, mature oocytes derived from prepubertal Merino ewe lambs (4-6 months) are less likely to reach the blastocyst stage after cleavage when compared to mature ewes (3-5 years, 7.4 v $24.6 \%$ respectively) suggesting that mature oocytes from prepubertal females do not possess the same potential for development (O’Brien et al, 1996). Further, fertilized oocytes derived from ewe lambs and mature ewes have similar cleavage rates, but there is a significant difference in the number of cleaved zygotes that develop to the blastocyst stage (mature ewes: $26.8 \%$ v lambs: 13.9 and $17.8 \%$; Kochhar et al, 2002). The embryos of peri-pubertal ewe lambs do not possess the same preimplantation developmental potential as embryos derived from mature ewes.

\subsubsection{Prenatal and Perinatal Mortality}

Prenatal mortality rates are elevated in ewe lambs compared to mature ewes due to a decrease in ova viability. Research has shown that there is no difference in embryonic survivability between ewe lambs and mature ewes ( 79 v $80 \%$ ) on embryonic day 15 , but by embryonic day 30 , the amount of ewe lambs containing viable fetuses decreased significantly compared to mature ewes (69 v 88\% respectively; Beck et al, 1996). This indicates that there is a higher rate of embryonic loss by 30 days of pregnancy in ewe lambs. This is thought to be associated with insufficient levels of progesterone; though, the mechanism for embryonic loss is not clearly defined.

Perinatal and postnatal mortality is elevated in neonates born to ewe lambs and this is predominately attributed to small size and low birthweights. Neonates of ewe lambs have the greatest probably of survival when born above $4.1 \mathrm{~kg}$, but the probability of mortality increases when lambs born to ewe lambs weigh between 3.3 and $4.1 \mathrm{~kg}$ at birth (McMillan and McDonald, 1983). Furthermore, ewe lambs have a decreased percentage of lambs that survive until weaning compared to mature ewes with singleton or twins ( $69 \mathrm{v} 84.7 \mathrm{v} 83.3 \%$ respectively); whereas, the 
lowest survivability of any neonate has been observed in twins born to ewe lambs (Corner-Thomas et al, 2013).

Nutrition during pregnancy is critical in maintaining productivity and a limited plane of nutrition during the early stages of gestation may contribute significantly to the weight and survivability of neonates. Mulvaney et al (2008) researched the effects of nutritional supplementation to ewe lambs during early pregnancy and birthweights. Ewe lambs were allocated to one of three different treatment groups: low, medium, or high. The low treatment group was fed pasture during the first 100 days of pregnancy to maintain liveweight. Then their nutritional plane was increased to gain $180 \mathrm{~g} /$ day until parturition. The medium nutritional treatment group was fed to maintain steady growth of $100 \mathrm{~g} /$ day throughout the entire gestational period. The high treatment group was fed $a d$ libitum. The results show that lambs born to ewe lambs in the low treatment group had lighter birthweights (18.1 v 20.6 v $21.8 \mathrm{lbs})$ and had lower survival rates (36 v 53 v 85\%) compared to the medium and high nutritional groups (Mulvaney et al, 2008). A subsequent study found that late gestational supplementation (medium-pre-grazing herbage mass of $1400 \mathrm{~kg} \mathrm{DM} / \mathrm{ha} \mathrm{v}$ ad libitum pre-grazing herbage with a minimum herbage mass of $1800 \mathrm{~kg} \mathrm{DM} / \mathrm{ha}$ ) after day 85 of pregnancy has no effect on lamb survival ( 80 v $78 \%$ respectively; Mulvaney et al, 2012), indicating that a high level of nutritional supplementation during early pregnancy is crucial for neonatal survivability and overall fertility of the ewe.

\subsubsection{Prolificacy}

Prolificacy varies significantly by breed whereas as Polypay is a highly prolific breed with ewe lambs having a $47 \%$ chance of multiple births. Conversely, the Columbia breed has an elevated likelihood of singles (1\% chance of multiple births), and breeds such as Targhee and Rambouillet are intermediate (13 and 14\% chance of multiple births respectively; Gaskins et al, 2005). 
However, ewe lambs have lower prolificacy compared to mature ewes (1.38 v 2.28) as demonstrated in texel crossbred breed (Annett and Carson, 2006), and is likely due to the decreased ovulation rate and the increased prenatal mortality rate as previously described. 


\subsection{Problem Statement}

In many sheep production systems, replacement females are bred between 16 and 20 months of age to lamb at about two years; however, ewe lambs reach puberty between seven and nine months, almost one year prior to first breeding. This extended development period between puberty and breeding increases costs and decreases lifetime productivity of each replacement ewe, hindering profitability of the enterprise. Moreover, conventionally developed replacements that fail to conceive can no longer be classified as slaughter lambs and are sold as culls at a discounted price. Therefore, breeding replacement females to lamb at one year of age presents as an opportunity to decrease production costs and increase lifetime productivity.

Fertility in ewe lambs is $20-30 \%$ lower than that of mature ewes, and is related to weight gain, nutritional status, and timing of estrous cyclicity. Heavier females reach puberty earlier, have a higher probability of becoming pregnant, greater pregnancy retention, and are more prolific. However, attainment of puberty is not directly correlated with age suggesting that various factors including breed, pre-breeding management, and breeding practices may have a greater impact on ewe lamb fertility. Genotypic and phenotypic variation among breeds also affects fertility outcome of replacement females and is particularly evident for breeds compared to breeds differing in prolificacy.

Failure of ewe lambs to conceive has been associated with an altered endocrine environment in the peripubertal animal. This period is marked by a transient rise in progesterone important for modulating ovarian activity. Breeding protocols utilizing exogenous progesterone or an analogue have been shown to increase estrous response, pregnancy to first service, and conception rates. Evidence in heifers suggests this is because progesterone treatment hastens the onset of puberty in helping overcome silent ovulations and the short lived corpus luteum. 
Furthermore, higher nutritional regimens resulting in increased liveweight gains and body condition have been positively correlated with increases in ovulation rates, estrous response, and prolificacy. The level and duration of supplementation and the exact amount of pre-breeding gains necessary for pubertal initiation and a positive fertility outcome are loosely defined. Therefore, the objective of this research is to evaluate the effects of pre-breeding management on ewe lamb fertility. 


\subsection{Introduction}

In many sheep production systems replacement ewe lambs comprise $30 \%$ of the breeding flock. Therefore, their individual productivity and fertility have a significant impact on overall productivity and profitability of the enterprise. Fertility of replacement females is $20-30 \%$ lower than that of adult ewes which can lower the overall profitability of the flock (Quirke et al, 1978). Between $20 \%$ and $40 \%$ of ewe lambs mated fail to lamb (Edey et al, 1978) due to decreased ovulation rates (Forrest and Bichard, 1974; Mulvaney et al 2013; Quirke and Hanrahan, 1977), decreased serum progesterone resulting in increased embryonic loss (Davies and Beck, 1993), low implantation rates (Quirke and Hanrahan, 1977), decreased pregnancy rates (Forrest and Bichard, 1974; Mulvaney et al 2013), and decreased prolificacy (Annett and Carson, 2006; Gaskins et al, 2005). Failure of ewe lambs to conceive during the breeding season have been associated with lighter live weights at breeding and lower weight gains between weaning and breeding (Gaskins et al, 2005; Hudgens et al,1987; Nieto et al, 2013). Interestingly, failure of ewe lambs to conceive is not correlated with age between 160-230 day of age (Gaskins et al, 2005; Rosales Nieto et al, 2013b). The ability for ewe lambs to conceive and lamb is dependent on puberty; however, puberty alone does not equate high fertility (Rosales Nieto et al, 2013b). This was demonstrated by Rosales Nieto et al (2013b) which showed that almost $90 \%$ of ewe lambs had attained puberty prior to breeding but only $36 \%$ of the ewe lambs conceived during two 21 day breeding periods.

Failure of ewe lamb to conceive has been associated with an altered endocrine environment and a transient rise in progesterone in the peripubertal animal, and breeding protocols using exogenous progesterone or a progesterone analogue have been utilized in an attempt to increase fertility in ewe lambs (Knights et al, 2002; Sawalha et al, 2011; Stellflug et al, 2001). The analogue medroxyprogesterone acetate (MAP, $60 \mathrm{mg}$ ) has been shown to increase pregnancy rate by $30 \%$ 
in progesterone pretreated ewe lambs compared to the control group (31 v 61\%, control and progesterone pretreated respectively; Stellflug et al, 2001). Additionally, in an out-of-season breeding study, fall-born ewe lambs pretreated with progesterone via a Controlled Internal Drug Releasing (CIDR; $0.3 \mathrm{~g}$ progesterone) device were able to display estrus and ovulate following ram introduction (Knights et al, 2002). In heifers, progestin treatment hastened the onset of puberty (Hall et al, 1997) and reduces the occurrence of silent ovulation and the short lived CL in animals induced to ovulate during the anestrous period (Ramirez-Godinez et al, 1981; Ramirez-Godinez et al, 1982).

Further, nutritional manipulations have been shown to affect the onset of puberty, fertility, and subsequently overall productivity of ewe lambs. Nutritional management affects daily gains and has the potential to advance the onset of puberty (Villa-Godoy et al, 1990). Regardless of breed, heavier females have a higher probability of becoming pregnant, retaining their pregnancy, and having multiple births. In addition, there is a positive correlation between average daily gains, breeding weight, body composition, and reproductive performance in Merino ewe lambs (Neito et al, 2013). Further, heavier females are more likely to be mated to the first estrous cycle following ram introduction, and have a greater chance of bearing twins rather than singles (Kenyon et al, 2006). However, there are breed variations associated with nutritional supplementation and fertility outcomes that can affect the outcome of nutritional supplementation. Prolificacy is one of the greatest breed difference associated with fertility with ewe lambs of the Polypay breed having a $47 \%$ chance of having multiple births compared to the Columbia breed having an elevated likelihood of singles with a $1 \%$ chance of multiple births. Breeds such as Targhee and Rambouillet have intermediate prolificacy with a $13 \%$ and a $14 \%$ chance of multiple births respectively (Gaskins et al, 2005). 
Additionally requirements for growth can vary significantly by breed and is associated with differences in mature weights. Large wool breeds such as Dorset and Texel ewes have a mature weight ranging from 67-91 kg; whereas, smaller wool breeds including Merino and Cheviot as well as tropical hair sheep such as Katahdin ewes have a mature range between $55-85 \mathrm{~kg}$. Therefore, it is essential to apply an adequate level of supplementation to obtain optimal weight gains and weight for breeding replacement females of each respective breed. Therefore, the objective of this research is to evaluate the effects of pre-breeding management on ewe lamb fertility. 


\subsection{Materials and Methods}

6.0.1Materials

The procedures used in these studies were approved by the West Virginia University Animal Care and Use Committee AICUC \#13-1101. The Controlled Internal Drug Release Device (CIDR) was obtained from Zoetis Animal Health, Kalamazoo, MI.

\subsection{Replicate 1}

6.1.1 Farm and animals

Research was conducted during the breeding seasons of 2014 and 2015 at West Virginia University's Reymann Memorial Farm in eastern West Virginia and at Wherry Farm in Scenery Hill, Pennsylvania.

A total of 313 Dorset X Texel (DT) ewe lambs and 74 Katahdin (KD) ewe lambs were utilized. All animals were reared on pasture with ad libitum forage and water, and supplemented concentrate.

\subsubsection{Experimental protocol}

Ewe lambs were balanced across nutritional treatments by birth type and age prior to being allocated to receive either high $(0.68 \mathrm{~kg} / \mathrm{head} / \mathrm{day})$ or low $(0.23 \mathrm{~kg} / \mathrm{head} /$ day $)$ grain supplementation containing 14\% crude protein for 2 months prior to breeding to achieve weight gains (5 and $10 \mathrm{kgs}$, respectively). Respective diets were supplemented for two months prior to breeding and live weights were recorded biweekly. Weight data were used to calculate changes in weight for the supplementation period, average daily gains (ADG) for the treatment period, and lifetime weight day averages (LWDA).

Prior to ram introduction (d-5), half of each treatment group were randomly selected to receive a progesterone pretreatment using an intravaginal CIDR (ZOETIS EAZI-BREED ${ }^{\text {TM }}$ CIDR ${ }^{\circledR} 0.3 \mathrm{~g}$ progesterone). On d0 progesterone treatment was removed and rams were introduced. All rams 
had fertility previously proven and were equipped with marking harnesses to determine estrous response.
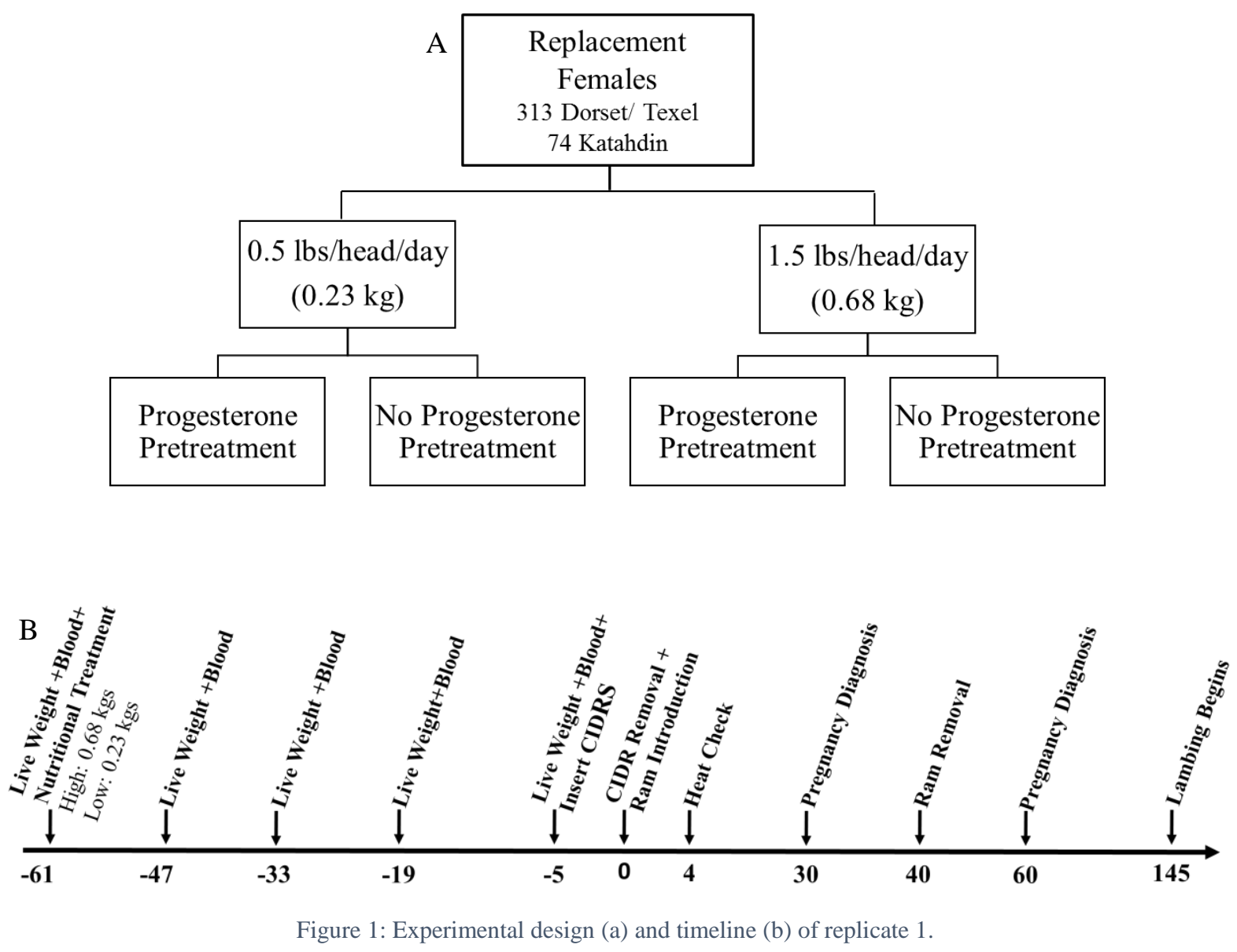

\subsection{Replicate 2}

\subsubsection{Farm and animals}

Research was conducted during the breeding season of 2016 at Wherry Farm in Scenery Hill, Pennsylvania.

A total of 68 Dorset X Texel (DT) ewe lambs ewe lambs were utilized for experimentation. All animals were reared on pasture with ad libitum forage and water, and supplemented concentrate according to the respective treatment group. 


\subsubsection{Experimental protocol}

Replicate 2 was conducted to evaluate the effect of providing higher levels of supplementation for a shorter duration on fertility of ewe lambs. Lambs were balanced based on age and birth type prior to receiving either high $(0.91 \mathrm{~kg} / \mathrm{head} /$ day $)$ or low $(0.45 \mathrm{~kg} / \mathrm{head} /$ day $)$ grain supplementation (14\% crude protein). Respective diets were supplemented for four weeks prior to estrous synchronization and liveweights were recorded biweekly. Weight data was utilized to calculate changes in liveweight, average daily gains, and lifetime weight day averages (LWDA).
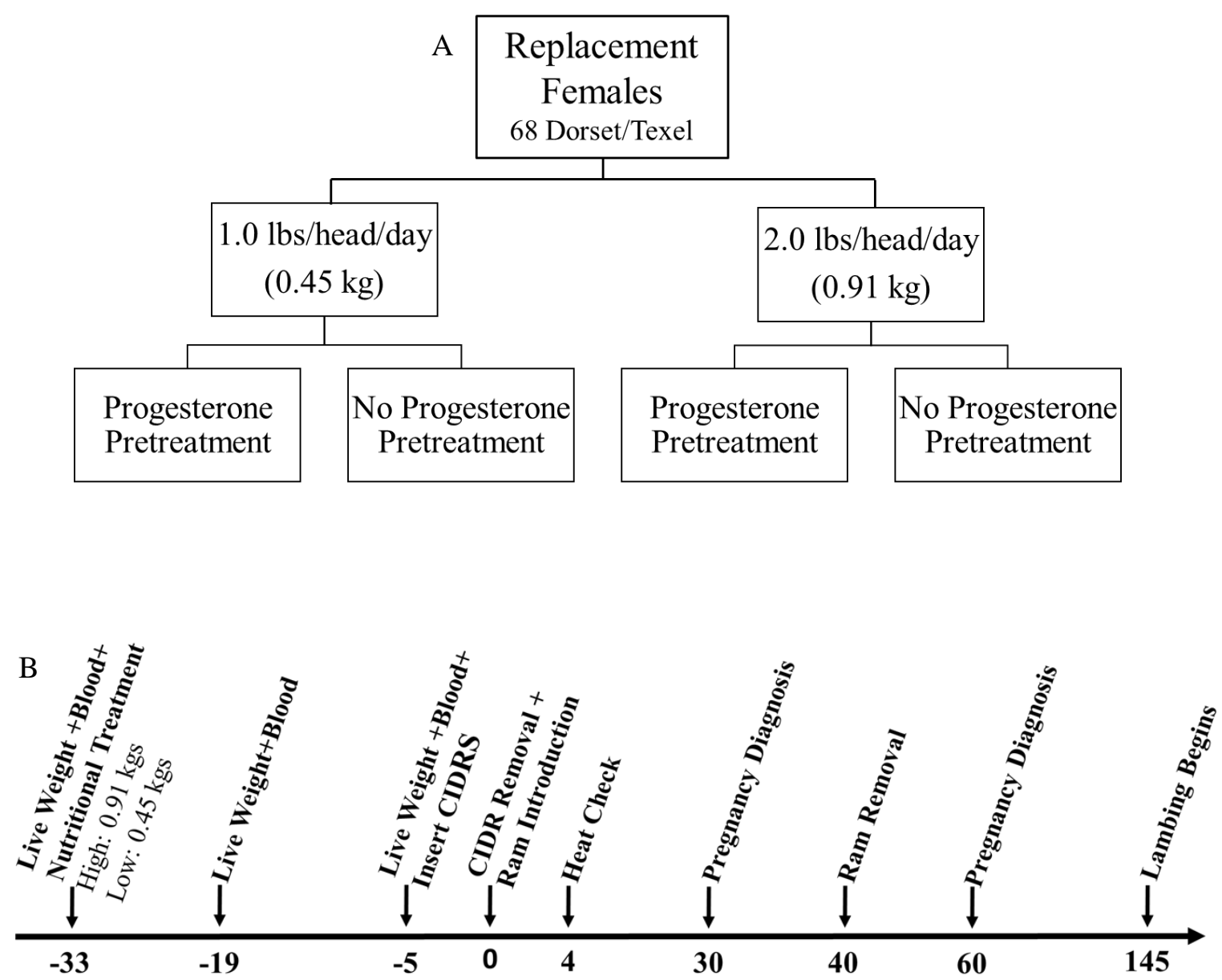

Figure 2: Experimental design (A) and timeline (B) of replicate 2. 


\subsection{Blood collection and progesterone quantification}

Blood samples were collected bi-weekly via jugular venipuncture at the start of the feeding period until CIDR insertion to determine if the ewe lambs were ovulating by the beginning of the the breeding period. Blood samples were collected into heparinized tubes (EDTA; Monoject, 15\% EDTA K3 liquid, Tyco Healthcare Group, Mansfield, Massachusetts, USA) and centrifuged for 20 minutes at 3000 rotations per minute. Plasma was harvested and stored at $-20^{\circ} \mathrm{C}$ until quantification of progesterone via I-125 radioimmunoassay (ImmuChem ${ }^{\mathrm{TM}}$ Double Antibody Progesterone 125-I RIA Kit, MP Biomedicals, Costa Mesa, CA). Progesterone concentration was measured in individual plasma samples and expressed as nanograms per milliliter (ng/ml). Values of greater than $1 \mathrm{ng} / \mathrm{ml}$ indicated puberty and were used to determine ovulatory status of each female.

\subsection{Estrous detection and ultrasonography}

Estrous response was determined by observation of raddle marks 96 hours after ram introduction. Following synchronization of estrus, pregnancy diagnosis using transrectal ultrasonography (Aloka 500 Corometrics Medical Systems, Wallingford, CT, USA with a $7.5 \mathrm{MHz}$ linear transducer) was conducted one month after ram introduction and overall pregnancy was determined two months after ram introduction. Lambing data was recorded. This data was used to determine conception rates, pregnancy to first service, overall pregnancy rates, and lambing rates.

\subsection{Breeding weight category, average daily gains category, and weight day average category}

Animals within each respective breed were classified by breeding weight, average daily gains for the treatment period, and weight day averages to determine their effects on reproductive responses. Groups were divided by calculating the mean \pm one half of the standard deviation (low: $\mathrm{L}<\mu-1 / 2$ STD, medium: $\mu-1 / 2$ STD $<\mathrm{M}<\mu+1 / 2$ STD, high: He $>\mu+1 / 2$ STD). Characteristics of each breed 
for breeding weight category, average daily gain category, and weight day average category are reported in Table 1.

Table 1 Description of ewe lamb characteristics

\begin{tabular}{|l|c|c|c|c|}
\hline \multirow{2}{*}{} & \multicolumn{2}{|c|}{ Replicate 1 } & Replicate 2 & $\begin{array}{c}\text { Pooled DT } \\
\text { Replicates }\end{array}$ \\
\cline { 2 - 5 } & Dorset X & Katahdin & Dorset X & Dorset X \\
\cline { 2 - 5 } & \multicolumn{4}{|c|}{ Average Daily Gain Category (g) } \\
\hline High & $138 \pm 3$ & $163 \pm 10$ & $99 \pm 6$ & $99 \pm 6$ \\
\hline Medium & $67 \pm 3$ & $100 \pm 7$ & $43 \pm 5$ & $43 \pm 5$ \\
\hline Low & $-27 \pm 5$ & $53 \pm 7$ & $-34 \pm 6$ & $-34 \pm 6$ \\
\hline High & $51.4 \pm 0.4$ & $36.6 \pm 1.0$ & $47.1 \pm 0.4$ & $51.4 \pm 0.4$ \\
\hline Medium & $40.1 \pm 0.4$ & $30.1 \pm 0.9$ & $41.6 \pm 0.4$ & $40.1 \pm 0.5$ \\
\hline Low & $32.8 \pm 0.6$ & $23.4 \pm 0.9$ & $35.4 \pm 0.4$ & $32.8 \pm 0.6$ \\
\hline & Lifetime Weight Day Average Category (g) \\
\hline High & $198 \pm 2$ & $176 \pm 4$ & $186 \pm 2$ & $198 \pm 2$ \\
\hline Medium & $159 \pm 2$ & $148 \pm 4$ & $146 \pm 2$ & $159 \pm 2$ \\
\hline Low & $117 \pm 2$ & $116 \pm 2$ & $98 \pm 2$ & $117 \pm 2$ \\
\hline
\end{tabular}

\subsection{Pooled DT Replicates:}

Data from Dorset X Texel ewe lambs from replicates 1 and 2 were pooled for statistical analysis to determine the main effects of nutritional treatment, progesterone pretreatment, breeding weight category, average daily gain category, weight day average category, and each respective interaction on this specific breed.

\subsection{Statistical analysis}

A two-way Analysis of Covariance (ANCOVA) was conducted using the PROC MIX procedure of SAS (Statistical Analysis System version 9.4 for Windows; SAS Institute, Cary, NC, USA) to determine the effect of nutritional treatment group, breed, progesterone pretreatment, breeding weight category, average daily gain category, weight day average category, and each respective interaction. Although nutritional treatment groups were balanced for age, breeding age was used as a covariate in the statistical model to increase the power to detecting treatment effects of breed, 
progesterone pretreatment, and each weight category. Additionally, an ANCOVA using the PROC MIXED procedure with breeding age as a covariate was used on the pooled replicate to determine if breeding weight, average daily gain for the treatment period, and weight day average differed in lambs experiencing a positive or negative reproductive outcome. All one degree comparisons were conducted using Tukey's LSD. All results are presented as least squares means \pm the standard error of the mean (LS Means \pm SEM) to account for unbalanced treatments. Results were considered significant at a confidence level of $\mathrm{P} \leq 0.05$, and a tendency when $0.05 \leq \mathrm{P} \leq 0.1$. 


\subsection{Results}

\subsection{Replicate 1}

7.1.1 Effect of Breed, Nutritional Treatment, and Progesterone Pretreatment on Growth and Reproductive Response of Ewe Lambs

Katahdin (KT) ewe lambs grew faster during the nutritional supplementation period, but Dorset X Texel (DT) ewe lambs were older and heavier at breeding, $(\mathrm{P}<0.0001$, Table 2$)$. More DT than KT ewe lambs ovulated prior to breeding $(\mathrm{P}<0.01)$, and DT ewe lambs showed a higher estrous response and more conceived to the $1^{\text {st }}$ service period $(\mathrm{P}<0.01$, Table 2$)$. Overall, animals on the high plane of nutrition grew at a greater rate, but no effect of nutritional supplementation on reproductive response or overall fertility was observed (Table 2).

Progesterone pretreatment did not impact reproductive response (Table 2), although more females that were not pre-treated with progesterone ovulated prior to breeding.

In ewe lambs that did not receive progesterone pre-treatment, more DT than KT conceived $(\mathrm{P}<$ $0.01,85 \pm 5$ v $53 \pm 10 \%$ respectively); however, a similar effect between breeds was not seen in ewe lambs receiving progesterone pre-treatment (Progesterone $\mathrm{X}$ Breed, $\mathrm{P}=0.05$ ).

Significantly more DT ewe lambs that were not pre-treated with progesterone $(\mathrm{P}=0.02,68 \pm 5 \mathrm{v}$ $54 \pm 3$, respectively) were pregnant to the first estrous cycle compared to those that received progesterone treatment; however, no difference $(\mathrm{P}=0.22)$ in pregnancy to first service was observed among progesterone treatments in KT ewe lambs (Progesterone X Breed, $\mathrm{P}=0.03$ ).

\subsubsection{Effect of Average Daily Gain (ADG) Prior to Breeding on Reproductive Response of Ewe} Lambs

The reproductive response of ewe lambs in low (L), medium (M) and high (H) ADG categories is presented in Table 3. Compared to animals in the L ADG category, animals in the H and M tended to have higher conception rates $(\mathrm{P}=0.09$ and $\mathrm{P}=0.06 \mathrm{~L} v \mathrm{M}$ and $\mathrm{L} v \mathrm{H}$, respectively), and more 
lambed $(\mathrm{P}=0.05$ and $\mathrm{P}=0.02 \mathrm{~L} v \mathrm{M}$ and $\mathrm{L} v \mathrm{H}$, respectively). Higher lambing rates were observed in ewe lambs in the $\mathrm{H}$ than in the $\mathrm{L}$ ADG category $(\mathrm{P}=0.02)$.

\subsubsection{Effect of Weight at Breeding on Reproductive Response of Ewe Lambs}

The reproductive response of ewe lambs in low (L), medium (M) and high (H) breeding weight categories is presented in Table 4.

Ewe lambs in the $\mathrm{M}$ and $\mathrm{H}$ breeding weight category showed a higher estrous response, pregnancy rate, proportion lambing, lambing rate, and a lower average age at first lambing than lambs in the L breeding weight category (Table 4; $\mathrm{P}<0.05$ ). However, no effect of breeding weight category on conception rate and number born was detected, and reproductive responses did not differ between ewe lambs in the $\mathrm{H}$ and $\mathrm{M}$ breeding weight categories.

DT ewe lambs had a more pronounced conception rate, pregnancy to first service, and age at first lambing (Table 4) in the $\mathrm{H}, \mathrm{M}$, and L breeding weight categories compared to KT ewe lambs in each respective category (Breed $\mathrm{X}$ Breeding Weight, $\mathrm{P}<0.05$ ).

7.1.4 Effect of Lifetime Weight Day Average (LWDA) Prior to Breeding on Reproductive Response of Ewe Lambs

Compared to the low (L) LWDA category, ewe lambs in the high (H) and medium (M) LWDA category showed a greater estrous response, pregnancy to first service, overall pregnancy rate, proportion lambing, lambing rate, and proportion achieve puberty by breeding (Table 5). This effect was more pronounced in DT than KT ewe lambs for most response variables (Breed X LWDA, $\mathrm{P}<0.05$ ) except for overall pregnancy and proportion lambing. 
Table 2 Effects of breed (DT v KT), nutritional treatment (H: $0.68 \mathrm{~kg} /$ head/day, L: $0.23 \mathrm{~kg} / \mathrm{head} / \mathrm{day}$ ), and progesterone pretreatment on growth and reproductive response of ewe lambs.

\begin{tabular}{|c|c|c|c|c|c|c|c|c|c|}
\hline \multirow{2}{*}{ Reproductive Response } & \multicolumn{3}{|c|}{ Breed } & \multicolumn{3}{|c|}{ Nutritional Treatment } & \multicolumn{3}{|c|}{ Progesterone Pretreatment } \\
\hline & Dorset & Katahdin & p-value & High & Low & p-value & Yes & No & p-value \\
\hline $\mathbf{n}$ & 313 & 74 & - & 193 & 194 & - & 259 & 128 & - \\
\hline Age at breeding (months) & $9.1 \pm 0.1$ & $6.9 \pm 0.2$ & $<0.0001$ & $8.0 \pm 0.2$ & $8.0 \pm 0.2$ & $\mathrm{NS}$ & $8.7 \pm 0.1$ & $8.7 \pm 0.02$ & NS \\
\hline Weight at breeding (kg) & $43.2 \pm 0.5$ & $29.5 \pm 0.9$ & $<0.0001$ & $42.9 \pm 0.7$ & $41.2 \pm 0.7$ & $\mathrm{NS}$ & - & - & - \\
\hline Average daily gain $(\mathrm{g})$ & $77 \pm 4$ & $97 \pm 8$ & $<0.0001$ & $160 \pm 7$ & $135 \pm 7$ & $<0.01$ & - & - & - \\
\hline Estrous response $(\%)$ & $74 \pm 3$ & $57 \pm 6$ & $<0.01$ & $62 \pm 4$ & $69 \pm 4$ & $\mathrm{NS}$ & $66 \pm 4$ & $66 \pm 4$ & NS \\
\hline Conception rate $(\%)$ & $77 \pm 3$ & $63 \pm 8$ & 0.09 & $66 \pm 6$ & $74 \pm 5$ & NS & $73 \pm 5$ & $69 \pm 6$ & NS \\
\hline Pregnancy $1{ }^{\text {st }}$ service $(\%)^{a}$ & $57 \pm 3$ & $38 \pm 6$ & $<0.01$ & $43 \pm 4$ & $52 \pm 5$ & NS & $49 \pm 5$ & $49 \pm 5$ & NS \\
\hline Pregnancy overall (\%) & $75 \pm 3$ & $65 \pm 6$ & NS & $70 \pm 4$ & $70 \pm 5$ & $\mathrm{NS}$ & $75 \pm 4$ & $65 \pm 4$ & $<0.1$ \\
\hline Proportion lambing (\%) & $60 \pm 3$ & $54 \pm 6$ & NS & $56 \pm 4$ & $58 \pm 5$ & NS & $60 \pm 5$ & $56 \pm 5$ & NS \\
\hline Lambing rate $(\%)^{b}$ & $69 \pm 4$ & $60 \pm 8$ & NS & $67 \pm 6$ & $63 \pm 7$ & NS & $68 \pm 6$ & $63 \pm 6$ & NS \\
\hline Age $1^{\text {st }}$ lambing (days) & $420 \pm 1$ & $423 \pm 2$ & NS & $422 \pm 1$ & $421 \pm 1$ & NS & $421 \pm 1$ & $422 \pm 1$ & NS \\
\hline Number born & $1.18 \pm 0.03$ & $1.10 \pm 0.06$ & NS & $1.2 \pm 0.046$ & $1.1 \pm 0.5$ & 0.09 & $1.1 \pm 0.05$ & $1.1 \pm 0.05$ & $\mathrm{NS}$ \\
\hline Ovulated prior to breeding (\%) & $26 \pm 2$ & $8 \pm 5$ & $<0.01$ & $16 \pm 4$ & $18 \pm 4$ & NS & $13 \pm 4$ & $26 \pm 4$ & 0.01 \\
\hline
\end{tabular}

a. Number of ewes diagnosed pregnant on day 30-35 as a percentage of all ewes exposed to rams.

b. Lambs born per ewe exposed to ram.

Values are least square means \pm SEM (number of animals). 
Table 3 Effect of average daily gain (DT, H: $138 \pm 3$ g, M: $67 \pm 3$ g, L: $-27 \pm 5$ g; KT, H: $163 \pm 10$ g, M: $100 \pm 7$ g, L: $53 \pm 7$ g) prior to breeding on reproductive response of ewe lambs.

\begin{tabular}{|c|c|c|c|c|c|c|}
\hline \multirow{2}{*}{ Reproductive Response } & \multicolumn{3}{|c|}{ Average Daily Gain Category } & \multirow[b]{2}{*}{ H v M } & \multirow[b]{2}{*}{$\mathbf{M} \mathbf{v} \mathbf{L}$} & \multirow[b]{2}{*}{ H v L } \\
\hline & High & Medium & Low & & & \\
\hline $\mathbf{n}$ & 143 & 152 & 83 & & & \\
\hline Estrous response (\%) & $73 \pm 6$ & $66 \pm 4$ & $61 \pm$ & NS & NS & $\mathrm{NS}$ \\
\hline Conception rate $(\%)$ & $76 \pm 7$ & $72 \pm 6$ & $57 \pm 7$ & NS & 0.09 & 0.06 \\
\hline Pregnancy $1^{\text {st }}$ service $(\%)^{a}$ & $56 \pm 6$ & $49 \pm 5$ & $36 \pm 6$ & NS & 0.08 & 0.02 \\
\hline Pregnancy overall (\%) & $70 \pm 6$ & $72 \pm 4$ & $63 \pm 6$ & NS & NS & NS \\
\hline Proportion lambing (\%) & $65 \pm 7$ & $60 \pm 5$ & $45 \pm 6$ & NS & 0.05 & 0.02 \\
\hline Lambing rate $(\%)^{b}$ & $79 \pm 9$ & $64 \pm 6$ & $51 \pm 8$ & NS & NS & 0.02 \\
\hline Age $1^{\text {st }}$ lambing (days) & $420 \pm 2$ & $423 \pm 1$ & $423 \pm 2$ & NS & $\mathrm{NS}$ & NS \\
\hline Number born & $1.2 \pm 0.06$ & $1.1 \pm 0.04$ & $1.1 \pm 0.07$ & 0.06 & NS & $\mathrm{NS}$ \\
\hline Ovulated prior to breeding (\%) & $18 \pm 5$ & $19 \pm 4$ & $12 \pm 5$ & NS & NS & NS \\
\hline
\end{tabular}

a. Number of ewes diagnosed pregnant on day 30-35 as a percentage of all ewes exposed to rams.

b. Lambs born per ewe exposed to ram.

Values are least square means \pm SEM (number of animals). 
Table 4 Effect of weight at breeding (DT, H: $51.4 \pm 0.4 \mathrm{~kg}, \mathrm{M}: 40.1 \pm 0.4 \mathrm{~kg}, \mathrm{~L}: 32.8 \pm 0.6 \mathrm{~kg}$; KT, H: $36.6 \pm 1.0 \mathrm{~kg}, \mathrm{M}: 30.1 \pm 0.9 \mathrm{~kg}, \mathrm{~L}: 23.4 \pm 0.9 \mathrm{~kg}$ ) on reproductive responses of DT and KT ewe lambs.

\begin{tabular}{|c|c|c|c|c|c|c|c|c|c|c|}
\hline \multirow[b]{3}{*}{ Reproductive Response } & \multicolumn{6}{|c|}{ Breeding Weight Category } & \multirow{2}{*}{\multicolumn{4}{|c|}{ P-Value }} \\
\hline & \multicolumn{3}{|c|}{ Dorset } & \multicolumn{3}{|c|}{ Katahdin } & & & & \\
\hline & High & Medium & Low & High & Medium & Low & H v M & $\mathbf{M} \mathbf{v L}$ & HvL & Interaction \\
\hline $\mathbf{n}$ & 129 & 118 & 64 & 22 & 27 & 22 & - & - & - & - \\
\hline Estrous response $(\%)$ & $90 \pm 4$ & $72 \pm 4$ & $49 \pm 5$ & $59 \pm 9$ & $68 \pm 8$ & $41 \pm 9$ & NS & $<0.001$ & $<0.0001$ & $<0.1$ \\
\hline Conception rate (\%) & $89 \pm 4$ & $74 \pm 4$ & $46 \pm 7$ & $59 \pm 12$ & $60 \pm 10$ & $76 \pm 15$ & NS & NS & NS & 0.01 \\
\hline Pregnancy $1^{\text {st }}$ service $(\%)^{a}$ & $80 \pm 4$ & $53 \pm 4$ & $23 \pm 6$ & $35 \pm 10$ & $40 \pm 9$ & $31 \pm 10$ & 0.1 & $<0.01$ & $<0.0001$ & $<0.01$ \\
\hline Pregnancy overall (\%) & $86 \pm 4$ & $76 \pm 4$ & $50 \pm 5$ & $71 \pm 9$ & $75 \pm 8$ & $43 \pm 9$ & NS & $<0.0001$ & $<0.0001$ & NS \\
\hline Proportion lambing ( $\%)$ & $71 \pm 4$ & $62 \pm 4$ & $42 \pm 6$ & $58 \pm 10$ & $62 \pm 10$ & $35 \pm 11$ & NS & $<0.01$ & $<0.01$ & NS \\
\hline Lambing rate $(\%)^{b}$ & $90 \pm 6$ & $67 \pm 6$ & $43 \pm 8$ & $61 \pm 14$ & $69 \pm 12$ & $39 \pm 14$ & NS & $<0.01$ & $<0.01$ & NS \\
\hline Age $1^{\text {st }}$ lambing (days) & $418 \pm 1$ & $419 \pm 1$ & $432 \pm 2$ & $426 \pm 3$ & $423 \pm 3$ & $421 \pm 4$ & NS & 0.03 & 0.07 & $<0.01$ \\
\hline Number born & $1.29 \pm 0.04$ & $1.1 \pm 0.04$ & $1.03 \pm 0.08$ & $1.0 \pm 0.10$ & $1.1 \pm 0.09$ & $1.0 \pm 0.10$ & $\mathrm{NS}$ & NS & $\mathrm{NS}$ & NS \\
\hline Ovulated prior to breeding (\%) & $39 \pm 4$ & $21 \pm 4$ & $11 \pm 5$ & $10 \pm 9$ & $6 \pm 8$ & $6 \pm 9$ & 0.08 & NS & 0.02 & NS \\
\hline
\end{tabular}

a. Number of ewes diagnosed pregnant on day 30-35 as a percentage of all ewes exposed to rams.

b. Lambs born per ewe exposed to ram.

Values are least square means \pm SEM (number of animals). 
Table 5 Effect of lifetime weight day average (DT, H: $198 \pm 2$ g, M: $159 \pm 2$ g, L: $117 \pm 2$ g; KT, H: $176 \pm 4$ g, M: $148 \pm 4$ g, L: $116 \pm 2$ g) prior to breeding on reproductive response of ewe lambs.

\begin{tabular}{|c|c|c|c|c|c|c|c|c|c|c|}
\hline \multirow[b]{3}{*}{ Reproductive Response } & \multicolumn{6}{|c|}{ Lifetime Average Daily Gain Category } & \multirow[b]{3}{*}{ H v M } & \multirow[b]{3}{*}{ Mv L } & \multirow[b]{3}{*}{ H v L } & \multirow[b]{3}{*}{ Interaction } \\
\hline & & Dorset & & & Katahdin & & & & & \\
\hline & High & Medium & Low & High & Medium & Low & & & & \\
\hline $\mathrm{n}$ & 135 & 92 & 84 & 21 & 23 & 28 & - & - & - & - \\
\hline Estrous response (\%) & $89 \pm 4$ & $78 \pm 4$ & $39 \pm 5$ & $67 \pm 9$ & $80 \pm 9$ & $55 \pm 8$ & NS & $<0.0001$ & $<0.0001$ & 0.02 \\
\hline Conception rate $(\%)$ & $90 \pm 4$ & $71 \pm 5$ & $54 \pm 8$ & $64 \pm 13$ & $69 \pm 11$ & $81 \pm 13$ & NS & NS & NS & 0.03 \\
\hline Pregnancy $1^{\text {st }}$ service $(\%)^{a}$ & $77 \pm 4$ & $56 \pm 5$ & $19 \pm 6$ & $44 \pm 10$ & $56 \pm 10$ & $45 \pm 9$ & NS & $<0.01$ & 0.0001 & $<0.001$ \\
\hline Pregnancy overall (\%) & $87 \pm 4$ & $73 \pm 5$ & $52 \pm 6$ & $76 \pm 10$ & $83 \pm 9$ & $57 \pm 9$ & NS & $<0.001$ & $<0.001$ & NS \\
\hline Proportion lambing (\%) & $73 \pm 4$ & $62 \pm 5$ & $36 \pm 6$ & $63 \pm 11$ & $76 \pm 10$ & $44 \pm 10$ & NS & $<0.001$ & $<0.001$ & NS \\
\hline Lambing rate $(\%)^{b}$ & $89 \pm 6$ & $75 \pm 7$ & $28 \pm 8$ & $71 \pm 14$ & $85 \pm 13$ & $56 \pm 12$ & NS & $<0.001$ & $<0.001$ & $<0.1$ \\
\hline Age $1^{\text {st }}$ lambing (days) & $418 \pm 1$ & $421 \pm 1$ & $427 \pm 2$ & $424 \pm 3$ & $421 \pm 3$ & $419 \pm 3$ & NS & NS & NS & 0.02 \\
\hline Number born & $1.3 \pm 0.04$ & $1.2 \pm 0.05$ & $0.9 \pm 0.07$ & $1.1 \pm 0.11$ & $1.3 \pm 0.10$ & $1.2 \pm 0.11$ & NS & NS & NS & 0.02 \\
\hline Ovulated prior to breeding (\%) & $32 \pm 3$ & $42 \pm 4$ & $-3 \pm 5$ & $18 \pm 9$ & $14 \pm 8$ & $14 \pm 8$ & NS & $<0.001$ & $<0.01$ & $<0.01$ \\
\hline
\end{tabular}

a. Number of ewes diagnosed pregnant on day 30-35 as a percentage of all ewes exposed to rams.

b. Lambs born per ewe exposed to ram.

Values are least square means \pm SEM (number of animals). 


\subsection{Replicate 2}

7.2.1 Effect of Nutritional Treatment and Progesterone Pretreatment on Growth and Reproductive Response of Ewe Lambs

Average daily gain and weight at breeding tended to be higher in ewe lambs receiving the high level of nutrition supplementation $(0.91 \mathrm{~kg} / \mathrm{head} / \mathrm{day}$ v $0.45 \mathrm{~kg} / \mathrm{head} / \mathrm{day} ; \mathrm{P}=0.09,51 \pm 9$ v $28 \pm 9 \mathrm{~g}$ and $\mathrm{P}=0.07,42 \pm 2 \mathrm{v} 40 \pm 1 \mathrm{~kg}$, respectively). More ewe lambs receiving the high than low level of supplementation showed estrus $(\mathrm{P}<0.01,100 \pm 5 \times 77 \pm 7 \%)$; however, no effect of level of supplementation on other reproductive response variables was observed.

No effect of progesterone pretreatment on reproductive responses was observed in replicate 2. Ewe lambs averaged 10.5 \pm 2.8 months of age at breeding.

\subsubsection{Effect of Average Daily Gain (ADG) Prior to Breeding on Reproductive Response of Ewe} Lambs

Ewe lambs in the M ADG category had or tended to have higher conception rate $(\mathrm{P}=0.06)$, pregnancy rate to the first service period $(\mathrm{P}=0.02)$, overall pregnancy rate $(\mathrm{P}=0.08)$, proportion lambing $(\mathrm{P}=0.03)$ and lambing rate $(\mathrm{P}=0.06)$ than lambs in the $\mathrm{L}$ ADG category (Table 6).

\subsubsection{Effect of Weight at Breeding on Reproductive Response of Ewe Lambs}

In replicate 2 , breeding weight category had no significant effect on reproductive response variables (data not shown).

\subsubsection{Weight day average category}

Reproductive outcomes increased with increasing weight day averages for most response variables (Table 7); however, there was no difference in the age at first lambing or prolificacy between the weight day average categories. 
Table 6 Effect of average daily gain (H: $99 \pm 6 \mathrm{~g}, \mathrm{M}: 43 \pm 5 \mathrm{~g}, \mathrm{~L}:-34 \pm 6 \mathrm{~g})$ prior to breeding on reproductive response of ewe lambs.

\begin{tabular}{|c|c|c|c|c|c|c|}
\hline \multirow[b]{2}{*}{ Reproductive Responses } & \multicolumn{3}{|c|}{ Average Daily Gain Category } & \multirow[b]{2}{*}{$\mathbf{H} \mathbf{v} \mathbf{M}$} & \multirow[b]{2}{*}{$\mathbf{M} \mathbf{v} \mathbf{L}$} & \multirow[b]{2}{*}{$\mathbf{H} \mathbf{v} \mathbf{I}$} \\
\hline & High & Medium & Low & & & \\
\hline $\mathbf{n}$ & 24 & 25 & 19 & - & - & - \\
\hline Estrous response (\%) & $88 \pm 7$ & $92 \pm 7$ & $83 \pm 8$ & NS & NS & NS \\
\hline Conception rate (\%) & $67 \pm 10$ & $78 \pm 10$ & $49 \pm 12$ & NS & 0.06 & NS \\
\hline Pregnancy $1^{\text {st }}$ service $(\%)^{a}$ & $59 \pm 10$ & $75 \pm 10$ & $40 \pm 11$ & NS & 0.02 & NS \\
\hline Pregnancy overall (\%) & $51 \pm 10$ & $67 \pm 10$ & $40 \pm 12$ & NS & 0.08 & NS \\
\hline Proportion lambing (\%) & $49 \pm 10$ & $62 \pm 11$ & $24 \pm 13$ & NS & 0.03 & NS \\
\hline Lambing rate $(\%)^{b}$ & $50 \pm 12$ & $67 \pm 12$ & $30 \pm 15$ & NS & 0.06 & NS \\
\hline Age $1^{\text {st }}$ lambing (days) & $459 \pm 1$ & $458 \pm 1$ & $454 \pm 2$ & NS & NS & 0.08 \\
\hline Number born & $1.0 \pm 0.08$ & $1.08 \pm 0.07$ & $1.24 \pm 0.13$ & NS & NS & NS \\
\hline Ovulated prior to breeding (\%) & $29 \pm 10$ & $40 \pm 10$ & $37 \pm 11$ & NS & NS & NS \\
\hline
\end{tabular}

a. Number of ewes diagnosed pregnant on day 30-35 as a percentage of all ewes exposed to rams.

b. Lambs born per ewe exposed to ram.

Values are least square means \pm SEM (number of animals). 
Table 7 Effect of lifetime weight day average (H: $186 \pm 2$ g, M: $146 \pm 2$ g, L: $98 \pm 2$ g) prior to breeding on reproductive response of ewe lambs.

\begin{tabular}{|c|c|c|c|c|c|c|}
\hline \multirow[b]{2}{*}{ Reproductive Responses } & \multicolumn{3}{|c|}{ Lifetime Weight Day Average Category } & \multirow[b]{2}{*}{$\mathbf{H} \mathbf{v} \mathbf{M}$} & \multirow[b]{2}{*}{$\mathbf{M} \mathbf{v} \mathbf{L}$} & \multirow[b]{2}{*}{$\mathbf{H} \mathbf{v} \mathbf{L}$} \\
\hline & High & Medium & Low & & & \\
\hline $\mathbf{n}$ & 21 & 21 & 26 & - & - & - \\
\hline Estrous response (\%) & $104 \pm 19$ & $91 \pm 13$ & $74 \pm 24$ & NS & NS & NS \\
\hline Conception rate (\%) & $145 \pm 26$ & $92 \pm 18$ & $-26 \pm 35$ & $<0.01$ & 0.02 & $<0.01$ \\
\hline Pregnancy $1^{\text {st }}$ service $(\%)^{a}$ & $140 \pm 26$ & $85 \pm 18$ & $-30 \pm 35$ & $<0.01$ & 0.03 & $<0.01$ \\
\hline Pregnancy overall $(\%)$ & $94 \pm 28$ & $62 \pm 20$ & $13 \pm 37$ & 0.08 & NS & NS \\
\hline Proportion lambing (\%) & $113 \pm 31$ & $61 \pm 20$ & $-17 \pm 38$ & 0.01 & NS & 0.06 \\
\hline Lambing rate $(\%)^{b}$ & $124 \pm 35$ & $70 \pm 23$ & $-24 \pm 43$ & 0.02 & NS & 0.06 \\
\hline Age $1^{\text {st }}$ lambing (days) & $457 \pm 4$ & $456 \pm 2$ & $459 \pm 7$ & NS & NS & NS \\
\hline Number born & $1.08 \pm 0.23$ & $1.17 \pm 0.13$ & $0.99 \pm 0.41$ & NS & NS & NS \\
\hline Ovulated prior to breeding (\%) & $-8 \pm 28$ & $20 \pm 20$ & $83 \pm 4$ & NS & NS & NS \\
\hline
\end{tabular}

a. Number of ewes diagnosed pregnant on day 30-35 as a percentage of all ewes exposed to rams.

b. Lambs born per ewe exposed to ram.

Values are least square means \pm SEM (number of animals). 


\subsection{Pooled DT Ewe Lambs:}

\subsubsection{Effect of Nutritional Treatment and Progesterone on Growth and Reproductive Response of}

Ewe Lambs

The average daily gain $(\mathrm{P}<0.001)$, was higher in ewe lambs receiving the high compared to the low level of supplementation; however, weight at breeding did not differ (Table 8).

Lambing rate tended to be higher $(\mathrm{P}=0.08)$ and prolificacy was significantly higher $(\mathrm{P}<0.01)$ in ewe lambs receiving the high compared to the low level of nutritional supplementation. More animals $(\mathrm{P}=0.02)$ receiving the low level of supplementation had ovulated prior to the breeding period. No effect of level of nutrition was observed for other reproductive response variables.

Compared to females that received progesterone pre-treatment, more females that did not receive pretreatment ovulated prior to breeding $(\mathrm{P}=0.0001)$ and were diagnosed pregnant to the first breeding period $(\mathrm{P}=0.03)$. Females that did not receive progesterone pre-treatment were heavier at the beginning of the breeding period $(\mathrm{P}<0.001)$.

In ewe lambs that did not receive progesterone pretreatment, more ewe lambs supplemented the low level of nutritional supplementation ovulated prior to breeding $(\mathrm{P}<0.01,56 \pm 6 \mathrm{v} 30 \pm 7$, respectively) compared to the $\mathrm{H}$ level of nutritional supplementation (Progesterone $\mathrm{X}$ Nutritional Treatment, $\mathrm{P}=0.02)$.

\subsubsection{Effect of Average Daily Gain (ADG) Prior to Breeding on Reproductive Response of Ewe} Lambs

With the exception of estrous response, number born and age at first lambing, all other reproductive performance variables were higher $(\mathrm{P}<0.01)$ ewe lambs in the $\mathrm{H}$ compared to the $\mathrm{L}$ ADG category. Ewe lambs in the M category had intermediate values were not significantly different from $\mathrm{H}$ and $\mathrm{L}$ categories (Table 9). 


\subsubsection{Effect of Weight at Breeding on Reproductive Response of DT Ewe Lambs (Pooled)}

More $\mathrm{H}$ ewe lambs ovulated before the start of the breeding period than in the $\mathrm{L}(\mathrm{P}<0.0001)$ or $\mathrm{M}$ breeding weight category $(\mathrm{P}<0.01)$.

Ewe lambs in the $\mathrm{H}$ breeding weight category had greater $(\mathrm{P}<0.01)$ reproductive responses than ewe lambs in the $\mathrm{L}$ and $\mathrm{M}$ with ewe lambs in the $\mathrm{M}$ category having intermediate values, except for proportion lambing and number born where there was no difference between the $\mathrm{H}$ and $\mathrm{M}$ and $\mathrm{M}$ and $\mathrm{L}$ categories respectively. Additionally, ewe lambs in the $\mathrm{H}$ and $\mathrm{M}$ categories lambed for the first time at a younger age than ewes in the L category $(\mathrm{P}<0.01$; Table 10$)$.

\subsubsection{Effect of Lifetime Weight Day Average (LWDA) Prior to Breeding on Reproductive Response} of Ewe Lambs

High and medium LWDA categories were significantly younger at breeding than the low LWDA category $(\mathrm{P}<0.0001,7.9 \pm 1.5$ v $9.1 \pm 1.7$ v $11 \pm 2.5$ respectively).

Reproductive response variables increased with increasing weight day averages in most response variables ( $\mathrm{P} \leq 0.05, \mathrm{P}<0.0001$ and $\mathrm{P}<0.05$ for $\mathrm{H} \vee \mathrm{M}, \mathrm{H} \vee \mathrm{L}$ and $\mathrm{M} \vee \mathrm{L}$, respectively; Table 11). Additionally, the age at first lambing was lower in ewe lambs in the H compared to the L LWDA category ( $\mathrm{P}=0.0002)$ with $\mathrm{M}$ LWDA ewe lambs being intermediate $(\mathrm{H} \vee \mathrm{M}, \mathrm{P}<0.05 ; \mathrm{M} \vee \mathrm{L}$, $\mathrm{P}=0.0004)$.

7.3.5 Average Breeding Weight, ADG, and WDA for positive and negative reproductive outcomes Breeding weights, ADG, and LWDA were significantly higher $(\mathrm{P}<0.05)$ in ewe lambs with a positive compared to a negative reproductive outcome for estrous response, conception rate, pregnancy to the first service, overall pregnancy rate, proportion lambing, and lambing to the first service period (Table 12). Additionally, ADG ( $169 \pm 44 \mathrm{v} 114 \pm 12$ v $85 \pm 5 \mathrm{~g}$ respectively) breeding weights $(61 \pm 5$ v $51 \pm 1$ v $44 \pm 1 \mathrm{~kg}$ respectively), and LWDA $(227 \pm 18$ v $189 \pm 5$ v $167 \pm 2 \mathrm{~g}$ 
respectively) were significantly higher $(\mathrm{P}<0.05)$ in ewe lambs having triplets and twins compared to those having singletons (Data not shown). 
Table 8: Effects of nutritional treatment (H: $0.68-0.91 \mathrm{~kg} / \mathrm{head} /$ day, $\mathrm{L}: 0.23-0.45 \mathrm{~kg} / \mathrm{head} / \mathrm{day})$, and progesterone pretreatment on reproductive responses of DT ewe lambs. Data was derived by pooling the data for DT ewe lambs in replicate 1 and replicate 2.

\begin{tabular}{|c|c|c|c|c|c|c|}
\hline \multirow[b]{2}{*}{ Reproductive Responses } & \multicolumn{3}{|c|}{ Nutritional Treatment } & \multicolumn{3}{|c|}{ Progesterone Pretreatment } \\
\hline & High & Low & p-value & Yes & No & p-value \\
\hline $\mathbf{n}$ & 151 & 162 & - & 226 & 87 & - \\
\hline Age at breeding (months) & $9.3 \pm 0.2$ & $9.2 \pm 0.2$ & NS & $9.2 \pm 0.2$ & $9.5 \pm 0.2$ & 0.02 \\
\hline Weight at breeding (kg) & $45 \pm 1$ & $43 \pm 1$ & NS & $42 \pm 1$ & $46 \pm 1$ & $<0.001$ \\
\hline Average daily gain (g) & $94 \pm 6$ & $65 \pm 6$ & $<0.0001$ & $74 \pm 5$ & $86 \pm 7$ & 0.1 \\
\hline Estrous response (\%) & $77 \pm 3$ & $75 \pm 3$ & NS & $74 \pm 3$ & $81 \pm 5$ & NS \\
\hline Conception rate $(\%)$ & $76 \pm 4$ & $79 \pm 4$ & NS & $74 \pm 3$ & $84 \pm 5$ & $<0.1$ \\
\hline Pregnancy $1^{\text {st }}$ service $(\%)^{a}$ & $58 \pm 4$ & $59 \pm 4$ & NS & $55 \pm 3$ & $68 \pm 5$ & 0.03 \\
\hline Pregnancy overall (\%) & $76 \pm 4$ & $73 \pm 3$ & NS & $76 \pm 3$ & $70 \pm 5$ & NS \\
\hline Proportion lambing (\%) & $63 \pm 4$ & $60 \pm 4$ & NS & $60 \pm 3$ & $65 \pm 5$ & NS \\
\hline Lambing rate $(\%)^{b}$ & $79 \pm 5$ & $66 \pm 5$ & 0.08 & $71 \pm 5$ & $75 \pm 7$ & NS \\
\hline Age $1^{\text {st }}$ lambing (days) & $429 \pm 1$ & $431 \pm 1$ & NS & $430 \pm 1$ & $430 \pm 2$ & NS \\
\hline Number born & $1.3 \pm 0.04$ & $1.1 \pm 0.04$ & $<0.01$ & - & - & - \\
\hline Ovulated prior to breeding (\%) & $26 \pm 4$ & $39 \pm 4$ & 0.02 & $21 \pm 3$ & $43 \pm 5$ & 0.0001 \\
\hline
\end{tabular}

a. Number of ewes diagnosed pregnant on day 30-35 as a percentage of all ewes exposed to rams.

b. Lambs born per ewe exposed to ram.

Values are least square means \pm SEM (number of animals). 
Table 9 Effect of average daily gain (H: $99 \pm 6 \mathrm{~g}, \mathrm{M}: 45 \pm 5 \mathrm{~g}$, L: $-36 \pm 6 \mathrm{~g}$ ) prior to breeding on reproductive response of DT ewe lambs. Data was derived by pooling the data for DT ewe lambs in replicate 1 and replicate 2 .

\begin{tabular}{|c|c|c|c|c|c|c|}
\hline \multirow[b]{2}{*}{ Reproductive Responses } & \multicolumn{3}{|c|}{ Average Daily Gain Category } & \multirow[b]{2}{*}{ H v M } & \multirow[b]{2}{*}{ M v L } & \multirow[b]{2}{*}{ H v L } \\
\hline & High & Medium & Low & & & \\
\hline Estrous response (\%) & $78 \pm 4$ & $77 \pm 4$ & $68 \pm 5$ & NS & NS & NS \\
\hline Conception rate (\%) & $82 \pm 4$ & $82 \pm 4$ & $59 \pm 6$ & NS & $<0.01$ & $<0.01$ \\
\hline Pregnancy $1^{\text {st }}$ service $(\%)^{a}$ & $64 \pm 4$ & $63 \pm 4$ & $40 \pm 6$ & NS & $<0.01$ & $<0.01$ \\
\hline Pregnancy overall (\%) & $80 \pm 4$ & $74 \pm 4$ & $64 \pm 6$ & NS & NS & 0.02 \\
\hline Proportion lambing (\%) & $68 \pm 4$ & $61 \pm 4$ & $49 \pm 6$ & NS & NS & 0.01 \\
\hline Lambing rate $(\%)^{b}$ & $86 \pm 6$ & $66 \pm 6$ & $58 \pm 9$ & 0.02 & NS & $<0.01$ \\
\hline Age $1^{\text {st }}$ lambing (days) & $430 \pm 1$ & $431 \pm 1$ & $433 \pm 1$ & NS & NS & NS \\
\hline Number born & $1.3 \pm 0.04$ & $1.1 \pm 0.048$ & $1.2 \pm 0.08$ & $<0.01$ & NS & NS \\
\hline Ovulated prior to breeding (\%) & $31 \pm 4$ & $29 \pm 4$ & $19 \pm 6$ & NS & NS & 0.09 \\
\hline
\end{tabular}

a. Number of ewes diagnosed pregnant on day 30-35 as a percentage of all ewes exposed to rams.

b. Lambs born per ewe exposed to ram.

Values are least square means \pm SEM (number of animals). 
Table 10 Effect of weight at breeding (H: $51.4 \pm 0.4 \mathrm{~kg}$, M: $40.1 \pm 0.5 \mathrm{~kg}, \mathrm{~L}: 32.8 \pm 0.6 \mathrm{~kg}$ ) on reproductive response of DT ewe lambs. Data was derived by pooling the data for DT ewe lambs in replicate 1 and replicate 2 .

\begin{tabular}{|c|c|c|c|c|c|c|}
\hline \multirow[b]{2}{*}{ Reproductive Responses } & \multicolumn{3}{|c|}{ Breeding Weight Category } & \multirow[b]{2}{*}{ H v M } & \multirow[b]{2}{*}{ M v L } & \multirow[b]{2}{*}{ H v L } \\
\hline & High & Medium & Low & & & \\
\hline Estrous response $(\%)$ & $91 \pm 4$ & $73 \pm 4$ & $50 \pm 5$ & $<0.001$ & $<0.001$ & $<0.0001$ \\
\hline Conception rate (\%) & $89 \pm 4$ & $74 \pm 4$ & $47 \pm 7$ & 0.01 & $<0.01$ & $<0.0001$ \\
\hline Pregnancy $1^{\text {st }}$ service $(\%)^{a}$ & $81 \pm 4$ & $54 \pm 4$ & $24 \pm 6$ & $<0.0001$ & $<0.0001$ & $<0.0001$ \\
\hline Pregnancy overall (\%) & $85 \pm 4$ & $75 \pm 4$ & $49 \pm 5$ & 0.07 & $<0.0001$ & $<0.0001$ \\
\hline Proportion lambing (\%) & $71 \pm 4$ & $61 \pm 4$ & $41 \pm 6$ & NS & $<0.01$ & 0.0001 \\
\hline Lambing rate $(\%)^{b}$ & $91 \pm 6$ & $67 \pm 6$ & $43 \pm 8$ & $<0.01$ & 0.02 & $<0.0001$ \\
\hline Age $1^{\text {st }}$ lambing (days) & $427 \pm 1$ & $429 \pm 1$ & $441 \pm 2$ & NS & $<0.0001$ & $<0.0001$ \\
\hline Number born & $1.3 \pm 0.04$ & $1.1 \pm 0.05$ & $1.0 \pm 0.08$ & $<0.01$ & NS & $<0.01$ \\
\hline Ovulated prior to breeding (\%) & $41 \pm 4$ & $23 \pm 4$ & $13 \pm 5$ & $<0.01$ & $\mathrm{NS}$ & $<0.0001$ \\
\hline
\end{tabular}

a. Number of ewes diagnosed pregnant on day 30-35 as a percentage of all ewes exposed to rams.

b. Lambs born per ewe exposed to ram.

Values are least square means \pm SEM (number of animals). 
Table 11 Effect of lifetime weight day average (H: 198 \pm 2 g, M: $159 \pm 2$ g, L:117 \pm 2 g) prior to breeding on reproductive response of DT ewe lambs. Data was derived by pooling the data for DT ewe lambs in replicate 1 and replicate 2.

\begin{tabular}{|c|c|c|c|c|c|c|}
\hline \multirow[b]{2}{*}{ Reproductive Responses } & \multicolumn{3}{|c|}{ Weight Day Average Category } & \multirow[b]{2}{*}{ H v M } & \multirow[b]{2}{*}{$\mathbf{M} \mathbf{v} \mathbf{L}$} & \multirow[b]{2}{*}{ H v L } \\
\hline & High & Medium & Low & & & \\
\hline $\bar{n}$ & 135 & 92 & 84 & - & - & - \\
\hline Estrous response (\%) & $92 \pm 4$ & $81 \pm 4$ & $43 \pm 5$ & 0.05 & $<0.0001$ & $<0.0001$ \\
\hline Conception rate (\%) & $91 \pm 4$ & $73 \pm 5$ & $55 \pm 7$ & $<0.01$ & 0.04 & 0.0001 \\
\hline Pregnancy $1^{\text {st }}$ service $(\%)^{a}$ & $81 \pm 4$ & $60 \pm 5$ & $23 \pm 6$ & $<0.001$ & $<0.0001$ & $<0.0001$ \\
\hline Pregnancy overall (\%) & $87 \pm 4$ & $74 \pm 4$ & $53 \pm 5$ & 0.02 & $<0.01$ & $<0.0001$ \\
\hline Proportion lambing (\%) & $75 \pm 4$ & $63 \pm 5$ & $38 \pm 6$ & 0.09 & $<0.01$ & $<0.0001$ \\
\hline Lambing rate $(\%)^{b}$ & $92 \pm 6$ & $79 \pm 7$ & $32 \pm 8$ & NS & $<0.0001$ & $<0.0001$ \\
\hline Age $1^{\text {st }}$ lambing (days) & $427 \pm 1$ & $431 \pm 1$ & $436 \pm 2$ & 0.05 & 0.02 & $<0.001$ \\
\hline Number born & $1.3 \pm 0.04$ & $1.2 \pm 0.05$ & $0.9 \pm 0.07$ & NS & $<0.001$ & $<0.0001$ \\
\hline Ovulated prior to breeding (\%) & $41 \pm 4$ & $23 \pm 4$ & $13 \pm 5$ & $<0.01$ & NS & $<0.0001$ \\
\hline
\end{tabular}

a. Number of ewes diagnosed pregnant on day 30-35 as a percentage of all ewes exposed to rams.

b. Lambs born per ewe exposed to ram.

Values are least square means \pm SEM (number of animals). 
Table 12 Average breeding weight, ADG, and LWDA for positive and negative reproductive outcomes in DT ewe lambs. Data was derived by pooling the data for DT ewe lambs in replicate 1 and replicate 2.

\begin{tabular}{|c|c|c|c|c|c|c|c|c|c|}
\hline \multirow{3}{*}{ Reproductive response } & \multicolumn{3}{|c|}{ Average daily gain (g) } & \multicolumn{3}{|c|}{ Breeding weight (kg) } & \multicolumn{3}{|c|}{ Lifetime weight day average (g) } \\
\hline & \multicolumn{2}{|c|}{$\begin{array}{c}\text { Reproductive } \\
\text { outcome }\end{array}$} & \multirow[b]{2}{*}{ p-value } & \multicolumn{2}{|c|}{$\begin{array}{c}\text { Reproductive } \\
\text { outcome }\end{array}$} & \multirow[b]{2}{*}{ p-value } & \multicolumn{2}{|c|}{$\begin{array}{c}\text { Reproductive } \\
\text { outcome }\end{array}$} & \multirow[b]{2}{*}{ p-value } \\
\hline & Yes & No & & Yes & No & & Yes & No & \\
\hline Estrous response & $83 \pm 5$ & $64 \pm 8$ & 0.03 & $45 \pm 1$ & $36 \pm 1$ & $\mathrm{P}<0.0001$ & $171 \pm 2$ & $144 \pm 3$ & $\mathrm{P}<0.0001$ \\
\hline Conception rate & $91 \pm 5$ & $58 \pm 9$ & $<0.01$ & $47 \pm 1$ & $40 \pm 1$ & $\mathrm{P}<0.0001$ & $174 \pm 2$ & $151 \pm 3$ & $\mathrm{P}<0.0001$ \\
\hline Pregnancy $1^{\text {st }}$ service $^{a}$ & $91 \pm 5$ & $62 \pm 6$ & $<0.001$ & $47 \pm 1$ & $39 \pm 1$ & $\mathrm{P}<0.0001$ & $177 \pm 2$ & $148 \pm 2$ & $\mathrm{P}<0.0001$ \\
\hline Pregnancy overall & $87 \pm 4$ & $54 \pm 8$ & $<0.001$ & $45 \pm 1$ & $39 \pm 1$ & $\mathrm{P}<0.0001$ & $170 \pm 2$ & $149 \pm 3$ & $\mathrm{P}<0.0001$ \\
\hline Proportion lambing & $91 \pm 5$ & $64 \pm 6$ & $<0.001$ & $45 \pm 1$ & $40 \pm 1$ & $\mathrm{P}<0.0001$ & $172 \pm 2$ & $155 \pm 3$ & $\mathrm{P}<0.0001$ \\
\hline Lambing to the $1^{\text {st }}$ service $^{b}$ & $96 \pm 6$ & $72 \pm 5$ & $<0.01$ & $47 \pm 1$ & $41 \pm 1$ & $\mathrm{P}<0.0001$ & $178 \pm 3$ & $158 \pm 2$ & $\mathrm{P}<0.0001$ \\
\hline Ovulated prior to breeding & $92 \pm 8$ & $72 \pm 5$ & 0.03 & $48 \pm 1$ & $42 \pm 1$ & $\mathrm{P}<0.0001$ & $177 \pm$ & $159 \pm 2$ & $\mathrm{P}<0.0001$ \\
\hline
\end{tabular}

a. Number of ewes diagnosed pregnant on day 30-35.

b. Number of ewes lambing by day 14 of the lambing period.

Values are least square means \pm SEM (number of animals) 


\subsection{Discussion}

The primary objective of this study was to evaluate the effects of pre-breeding overall fertility in nulliparous sheep. This was done with the intent to apply research findings to lamb production in the North Eastern United States. The present study demonstrated that (i) ewe lambs with heavier breeding weights have an increased reproductive response, (ii) progesterone pretreatment may not be necessary to advance estrous response at breeding in replacement females that have achieved adequate growth to undergo the pubertal transition, and (iii) achieving higher weight day averages rather than focusing on gains during the pre-breeding period allows for greater control of the reproductive response of ewe lambs.

\subsection{Breed effects}

Large variation and confounding effects of breed, environment, and farming system limit the ability to compare the difference in reproductive responses between Dorset X Texel (DT) and Katahdin (KT) ewe lambs. Even so, more DT than KT ewe lambs attained puberty (ovulated) prior to breeding, and DT ewes showed a higher fertility at first service; however, there was no significant effect of breed on overall fertility or lambing rate. The increase in the percentage of DT ewe lambs cyclic prior to breeding could be attributed to the differences in age and weight at breeding (9 v 7 months and 43 v $29 \mathrm{~kg}$ for DT and KT ewe lambs, respectively). Despite KT ewe lambs being younger and lighter at breeding, they grew at a faster rate during the pre-breeding period. Given additional growth during the breeding period, more KT lambs could have been bred at subsequent service periods potentially resulting in similar overall lambing rate in the two breeds. 


\subsection{Nutritional treatment}

An elevated plane of nutrition had no effect on fertility in the immediate pre-breeding period which is contradictory to current literature in ewe lambs (Bizelis et al, 1990; Burfening and Bererdinelli, 1986) and heifers (Mackey et al, 2000; Schillo et al, 1992; Villa-Godoy et al, 1990). In ewe lambs, elevated nutrition has been shown to advance puberty, stimulate a higher ovulation rate, and stimulate the estrous response (Bizelis et al, 1990; Burfening and Bererdinelli, 1986). Additionally, in dairy heifers, an increased plane of nutrition has been shown to advance puberty; whereas a restricted nutritional plane delayed puberty and resulted in the inability of the heifers to competently support pregnancy (Villa-Godoy et al, 1990). Acute nutritional restriction induced anestrous in cycling heifers (Mackey et al, 2000) and delayed puberty in prepubertal heifers (Day et al, 1986). Feed restriction can suppress the estrous cycle and reproductive behavior when fat deposits are not available to cover demands (Bronson, 2000; Schneider and Wade, 2000). Ewe lambs that lack sufficient dietary energy in the prepubertal period exhibit an extended response to negative feedback of estrogen (Foster et al, 1986). This is associated with concentrations of systemic leptin signaling body condition and being permissive of the pubertal transition (Cordoso et al, 2014; Foster and Nagatani, 1999; Rosales Nieto et al, 2014; Samadi et al, 2014).

In the present study the lack of observed differences in reproductive responses in ewe lambs fed different levels of supplementation is presumably due to the type and length of supplemental feeding. The present study used a diet containing $77.3 \%$ total digestible nutrients (TDN) and $15.6 \%$ crude protein $(\mathrm{CP})$, which is higher than the recommended diet for $44 \mathrm{~kg}$ ewe lamb (64.5\% TDN and $12.6 \% \mathrm{CP})$. When ewe lambs were fed a control (75\% TDN and 15\% CP) or nutrient restricted diet $(60 \%$ TDN and $11.4 \% \mathrm{CP})$ for one month prior to breeding, it was observed that dietary 
restriction delayed age but not weight at puberty (Boulanouar et al, 1995). This suggests that weight is a limiting factor in the attainment of puberty.

Bizelis et al (1990) supplemented ewe lambs with a high plane of nutrition starting at 85 days of age and observed increased ovulation rate and estrous responses. Additionally, Burfening and Berardinelli (1986) supplemented replacement ewes with either a high or a low energy supplement for three months prior to breeding and reported a significant effect on proportion lambing.

Finally, the system of feeding could have resulted in significant within treatment variation in weight gains which would have precluded the detection of differences in reproductive responses across nutrition supplementation treatments.

\subsection{Breeding weight category}

Due to the expected within nutrition treatment variation in weight gains, ewe lambs within breed were classified based on observed weight gains and breeding weight. A greater percentage of ewe lambs classified as having high breeding weights attained puberty compared to those classified as low weight ewe lambs. This finding is consistent with the Critical Body Weight Hypothesis which suggest that heavier females reach puberty at a younger age (Frisch and McArthur, 1974).

Females that were heavier at breeding were more likely to express estrus, conceive and become pregnant to the first service. This positive impact of weight at breeding on fertility is consistent with current literature in ewe lambs and heifers, and has been associated with an increased body composition, which allows for a greater proportion of ewe lambs to have initiated cyclicity prior to breeding.

Several authors report body condition is positively related to liveweight (Geisler and Fenlon et al 1979; Kenyon et al 2004a; Russel et al, 1969; and Sanson et al 1993), and a positive correlation 
between breeding weights and reproductive performance in ewe lambs has also been observed (Rosales Nieto et al, 2013b). Kenyon et al (2009 and 2010) demonstrated an advanced estrous response in heavier and higher conditioned females compared to lighter weight females and those with a lower body condition score. Additionally, as body condition increases, a successive increase in pregnancy rates is observed $(\mathrm{BCS} 1.5=63.7 \%$ v BCS $2.0=76 \%$ v BCS $2.5=83 \%$; Kenyon et al, 2010). Rosales Nieto et al (2013b) quantified this effect demonstrating that a $4 \%$ increase in estrous response with each $20 \mathrm{~g}$ increase in average daily gain in the pre-breeding period (70 days prior to breeding). Consequently, there is a threshold weight and body condition beyond which achieving greater gains and conditioning prior to breeding will cease to have an effect on fertility. In composite ewe lambs, a bodyweight threshold showed no benefit to additional liveweight gains greater than $47.5 \mathrm{~kg}$, but significant differences in fertility and reproductive rates were observed prior to $47.5 \mathrm{~kg}$ (Corner-Thomas et al, 2015). This is in agreement with the findings of Kenyon et al (2008, 2009, 2010), and Rosales Nieto et al (2013b). Additionally, a 90\% fertility (number of ewe lambs pregnant/ 100 ewes bred) was achieved at a threshold body condition score of 3.5 and reproductive rate (number of fetuses/ 100 ewes bred) peaked at $130 \%$ with a 3.0 body condition score (Corner-Thomas et al, 2015).

In the present study the lambing rate increased with increasing body weight. This finding is supported by the work on Kenyon et al $(2006,2008,2009)$ and demonstrates that heavier ewe lambs are more likely to become pregnant and carry multiple lambs. Liveweights are the most significant factor affecting the number of fetuses present one month after ram introduction (Kenyon et al, 2004b). 
Interestingly, heavier females were younger at their first lambing. This suggest that beyond a threshold age, weight gain and weight at breeding may be the major determinants of fertility in ewe lambs.

It is beneficial to know the specific weights associated with positive reproductive outcome. Therefore, an ANCOVA with breeding age as the covariate was utilized to evaluate each reproductive outcome as the dependent variable. Data suggests that for DT ewe lambs, a breeding weight of $45 \mathrm{~kg}$ is ideal for replacement females to express estrus, become pregnant, and lamb. However, to advance the estrous response, become pregnant, and lamb to the first service, ewe lambs should average $47 \mathrm{~kg}$ at breeding. A liveweight of $40 \mathrm{~kg}$ was suggested for Merino ewe lambs to be bred to the first estrous cycle (Kenyon et al, 2005; Kenyon et al, 2006; Kenyon et al, 2009), and $45 \mathrm{~kg}$ for Merino ewe lambs to have high reproductive rates (Rosales Neito et al. 2013a). Though within flock, the variation in pubertal weight can vary significantly (Dyrmundsson et al, 1972); it is suggested that $50-70 \%$ of the mature liveweight is the critical range for ewe lambs to undergo the pubertal transition (Hafez, 1952; Dyrmundsson, 1973). In the Merino breed, there is a linear response between liveweight and the pregnancy response in ewe lambs between 30 and $45 \mathrm{~kg}$ (Rosales Nieto et al, 2013a). This threshold effect is similar to that observed in mature ewes (Ferguson et al, 2011). In the present study, breeding weights of $51 \mathrm{~kg}$ and $61 \mathrm{~kg}$ were necessary for increased prolificacy. Presumably, this is to ensure that ewe lambs have a great enough liveweight and body composition for not only high ovulation rates but maturity to support multiple fetuses. In Merino ewe lambs, each additional kg liveweight gain prior to the suggested threshold of $47.5 \mathrm{~kg}$ resulted in 4.8 more fetuses per 100 Merino ewe lambs (Rosales Nieto, 2013a).

Regardless of breed, heavier females have a higher probability of becoming pregnant, retaining their pregnancy and having multiple births. Elevated liveweight and body condition are permissive 
of puberty and subsequently enhance fertility response in nulliparous females. Overfeeding to achieve a breeding weight that is substantially higher than threshold is not economically beneficial. Therefore, efficient nutritional management is necessary to optimize reproductive performance in the first breeding season.

\subsection{Progesterone pretreatment}

Progesterone pretreatment was shown to advance the first estrous response in nulliparous females (Knights et al., 2002; Sawalhah et al., 2011; Stellflug et al. 2001). However, in the present study ewe lambs that were not pre-treated with progesterone showed higher reproductive rates. This is likely due to the greater proportion of non-progesterone pretreated ewes that attained puberty prior to the breeding season resulting in a high estrous and pregnancy rate to the first service period.

These findings indicate that if lambs can be fed to grow at a sufficient rate and reach the threshold weight and body condition score to attain puberty prior to the breeding season a significant proportion will conceive during the first service period.

\subsection{Average daily gains in the immediate pre-breeding period}

Ewe lambs achieving high daily gains in the period prior to the breeding season showed improved reproductive outcomes. Increasing the average daily gains in the pre-breeding period was also previously shown to improve reproductive responses and overall fertility in ewe lambs (Bizelis et al, 1990; Burfening and Bererdinelli, 1986), and heifers (Cardoso et al, 2014). In contrast Rosales Nieto et al (2013a) found no effect of increased average daily gains during the prebreeding period in Merino ewe lambs and suggested this was due to the already elevated average daily gains being 
obtained (> 200 grams/day). Similarly, heifers experiencing a rapid rate of gain during this period exhibited a lower estrous response than slower growing heifers (Ferrel et al, 1982).

Data from this experiment indicates that ewe lambs should gain $>91 \mathrm{~g} / \mathrm{d}$ in the immediate prebreeding period to express estrous, become pregnant, and lamb. Further, to support multiple fetuses, ewe lambs would need to gain $114 \mathrm{~g} / \mathrm{d}$ for multiple births.

The present study is in agreement with the work of Boulanouar et al (1995) who suggested that short term increases in the plane of nutrition to achieve greater gains during this period may not be always be sufficient in overcoming long term nutrient restrictions. Ewe lambs that switched from a restricted protein or restricted energy diet to a control diet were heavier at breeding and gained more weight during the treatment period, but were unable to achieve puberty earlier than lambs fed solely a restricted diet (Boulanouar et al, 1995).

\subsection{Weight day average}

Elevated lifetime weight day average gains significantly enhanced fertility in replacement females. There was a successive increase in estrous response, conception rate, pregnancy outcomes, proportion lambing, lambing rate, and prolificacy as weight day averages increases. Faster growth results in ewe lambs achieving puberty at a younger age (Rosales Nieto et al 2013a, Hawker and Kennedy, 1978); thus, allowing ewe lambs to be mated at a younger age. It is important to note that the animals with higher weight day averages were younger at breeding and were younger at first lambing than animals that grew at a slower rate.

Replacement females that conceived and lambed to their first breeding season achieved weight day averages $>172 \mathrm{~g}$ per day. Additionally, ewe lambs that produced multiple progeny achieved weight day averages $>189 \mathrm{~g}$ per day. 


\subsection{Conclusion}

There is some evidence that increasing the level of nutritional supplementation and increasing average daily gain in the immediate pre-breeding period can impact fertility; however, a shortterm increase in supplementation may not be enough to overcome previous nutrient restrictions or light weight gains. Therefore, achieving higher gains over the animal's lifetime rather than focusing on the pre-breeding period may be of greater concern. Increasing weight day averages has the greatest impact on fertility responses in nulliparous females. Furthermore, sufficiently supplementing ewe lambs may provide a way to advance the estrous response and pregnancy to first service without having to rely on the use of progesterone pretreatment in the synchronization protocol for breeding replacement females. 


\subsection{References}

Abecia JA, Forcada F, and Gonzalez-Bulnes A. (2012). Hormonal control of reproduction in small ruminants. Animal Reproduction Science, 130:173-179.

Afolayan RA, Fogarty NM, Gilmour AR, Ingham VM, Gaunt GM, and Cummins LJ. (2008). Reproductive performance and genetic parameters in first cross ewes from different maternal genotypes. Journal of Animal Science, 86(4):804-814.

Ahren B, Larsson H, Wilhelmsson C, Nasman B, and Olsson T. (1997). Regulation of circulating leptin in humans. Endocrine, 7:1-8.

Allen CC, Alves BRC, Li X, Tedeschi LO, Zhou H, Paschal JC, Riggs PK, Braga-Neto UM, Keisler DH, Williams GL, and Amstalden M. (2012). Gene expression in the arcuate nucleus of heifers is affected by controlled intake of high- and low-concentrate diets. Journal of Animal Science, 90:2222-2232.

Annett RW and Carson AF. (2006). Effects of plane of nutrition during the first month of pregnancy on conception rate, foetal development and lamb output of mature and adolescent ewes. Animal Science, 82(6): 947-954.

Backholer K, Smith JT, Rao A, Periera A, Iqbal J, Ogawa S, Li Q, and Clarke IJ. (2010). Kisspeptin cells in the ewe brain repspond to leptin and communicate with neuropeptide $\mathrm{Y}$ and proopiomelanocortin cells. Neuroendocrinology, 151:2233-2243.

Bakker J, De Mees C, Douhard Q, Balthazart J, Gabant P, Szpirer J, and Szpirer C. (2006). Alphafetoprotein protects the developing female mouse brain from masculinization and defeminization by estrogens. Nature Neuroscience, 9(2):220-226.

Barrell GK, Moenter SM, Caraty A, and Karsch FJ. (1992). Seasonal changes of gonadotropin-releasing hormone secretion in the ewe. Biology of Reproduction, 46:1130-1135.

Bassett JM, Oxborrow TJ, Smith ID, and Thorburn GD. (1969). The concentration of progesterone in the peripheral plasma of the pregnant ewe. Journal of Endocrinology, 45:449-457.

Bazer FW, Vallet JL, Harney JP, Gross TS, and Thatcher WW. (1989). Comparative aspects of maternal recognition of pregnancy between sheep and pigs. Journal of Reproduction and Fertility Supplement, 37:85-89.

Bearden HJ, Fuquay JW, and Willard ST. (2004). Applied Animal Reproduction. Prentice Hall.

Beck NF, Davies M, Gwynne MG, and Davies B. (1996). A comparison of ovulation rate and late embryonic mortality in ewe lambs and ewes and the role of late embryo loss in ewe lamb subfertility. Journal of Animal Science, 62:79-83.

Bergfeld EGM, Kojima FN, Cupp AS, Wherman ME, Peters KE, Garcia-Winder M, and Kinder JE. (1994). Ovarian follicular development in prepubertal heifers is influenced by level of dietary energy intake. Biology of Reproduction, 51:1046-1050.

Bindon BM, and Turner HN. (1974). Plasma LH of the prepubertal lamb: A possible early indicator of fertility. Journal of Reproduction and Fertility, 39:85-88. 
Bizelis JA, Deligeorgis SG, and Rogdakis E. (1990). Puberty attainment and reproductive characteristics in ewe lambs of Chios and Karagouniko breeds raised on two planes of nutrition. Animal Reproduction Science, 23(3):197-212.

Boulanouar B, Ahmed M, Klopfenstein T, Brink D, and Kinder J. (1995). Dietary protein or energy restriction influences age and weight at puberty in ewe lambs. Animal Reproduction Science, 40:229-238.

Bowstead JE. (1930). The effect of breeding immature ewes. Scientific Agriculture, 10(7):429-459.

Bronson FH. (2000). Puberty and energy reserves: A walk on the wild side. In E. K. Schneider, Reproduction in Context (pp. 15-33). Cambridge, MA: MIT Press.

Burfening PJ and Berardinelli JG. (1986). Effect of feed treatment and exogenous estrogen and progestogen on puberty and lambing rates in ewe lambs. Journal of Animal Science, 63(6):17171721.

Cardoso RC, Alves BRC, Prezotto LD, Thornson JF, Tedeschi LO, Keisler DH, Amstalden M, and Williams GL. (2014). Reciprocal changes in leptin and NPY during nutritional accelertation of puberty in heifers. Journal of Endocrinology, 223:289-298.

Casida LE and Warwick EJ. (1945). The necessity of the corpus luteum for maintenance of pregnancy in the ewe. Journal of Animal Science, 4:34-36.

Cave LM, Kenyon PR, and Morris ST. (2012). Effect of timing of exposure to vasectomised rams and ewe lamb body condition score on the breeding performance of ewe lambs. Animal Production Science, 52:471-477.

Chehab FF, Mounzih K, Lu R, and Lim ME. (1997). Early onset of reproductive function in normal female mice treated with leptin. Science, 275:88-90.

Cheung CC, Thornton JE, Kuijper JL, Weigle DS, Clifton DK, and Steiner RA. (1997). Leptin is a metabolic gate for the onset of puberty in the female rat. Endocrinology, 138:855-857.

Clarke IJ, Sari IP, Qi Y, Smith JT, Parkinton HC, Ubuka T, Iqbal J, Li Q, Tilbrook A, Morgan K, Pawson AJ, Tsutsui K, Miller RP, Bentley GE. (2008). Potent action of RFamide-related peptide-3 on pituitary gonadotropes indicative of a hypophysiotropic role in negative regulation of gonadotropin secretion. Endocrinology, 146:5811-5821.

Congnie Y, Gray SJ, Lindsay DR, Oldham CL, and Pearce DT. (1982). A new approach to controlled breeding in sheep using the ram effect. Proceedings: Australian Society of Animal Production, 14:519-522.

Cooper DA, Carver DA, Villeneuve P, Silvia WJ, and Inskeep EK. (1991). Effects of progestagen treatment on concentrations of prostaglandins and oxytocin in plasma from the posterior vena cava of post-partum beef cows. Journal of Reproduction and Fertility, 91:411-421.

Corner-Thomas RA, Mulvaney FJ, Morris ST, West DM, Morel PCH, and Kenyon PR. (2013). A comparison of the reproductive performance of ewe lambs and mature ewes. Small Ruminant Research, 114:126-133. 
Corner-Thomas RA, Ridler AL, Morris ST, and Kenyon PR. (2015). Ewe lamb liveweight and body condition scores affect reproductive rates in commercial flocks. New Zealand Journal of Agricultural Research, 58:26-34.

Davies MCG and Beck NFG. (1993). A comparison of plasma prolactin, LH and progesterone concentrations during oestrus and early pregnancy in ewe lambs and ewes. Cambridge University Press, 57(2):281-286.

Day ML, Imakawa K, Zalesky DD, Kittok RH, and Kinder JE. (1986). Effects of dietary energy intake during the prepubertal period on secretion of luteinizing hormone and responsiveness of the pituitary to luteinizing-hormone releasing hormone in heifers. Journal of Animal Science, 62:1641-1648.

Dyrmundsson OR. (1972). Attainment of puberty and reproductive performance in Clun Forest ewe lambs. The Journal of Agricultural Science, 78(1):39-45.

Dyrmundsson OR. (1973). Puberty and early reproductive performance in Sheep. I. Ewe lambs. Animal Breeding Abstracts, 273-289.

Ebling FJ, and Foster DL. (1988). Photoperiod requirements for puberty differ from those for the onset of the adult breeding season in the female sheep. Journal of Reproduction and Fertility, 84:283-293.

Echternkamp SE, and Laster DB. (1976). Plasma LH concentrations for prepubertal, postpubertal anestrous, and cyclic ewes of varying fecundity. Journal of Animal Science, 42:444-447.

Edey TN, Kilgour R, and Bremner K. (1978). Sexual behaviour and reproductive performance of ewe lambs at and after puberty. The Journal of Agricultural Science, 90, 83-91.

Fabre-Nys C, and Martin GB. (1991a). Hormonal control of proceptive and receptive sexual behavior and the preovulatory LH surge in the ewe: Reassessment of the respective roles of estradiol, testosterone, and progesterone. Hormones and Behavior, 25(3): 295-312.

Fabre-Nys C, and Martin GB. (1991b). Roles of progesterone and oestradiol in determining the temporal sequence and quantitative expression of sexual receptivity and preovulatory LH surge in the ewe. Journal of Endocrinology, 130:367-379.

Fabre-Nys C and Gelez H. (2007). Sexual behavior in ewes and other domestic ruminants. Hormones and Behavior, 52:18-25.

Fabre-Nys C, Kendrick KM, and Scaramuzzi RJ. (2015). The "ram effect": New insights into neural modulation of the gonadotropic axis by male odors and socio-sexual interactions. Frontiers in Neuroscience, 9(111): 1-16.

Ferguson MB, Kennedy AJ, Young JM and Thompson AN. (2011). The roads to efficiency in the ewe flock. Recent Advances in Animal Nutrition-Australia, 18:37-42.

Ferrel CL. (1982). Effects of postweaning rate of gain on onset of puberty and reproductive performance in heifers of different breeds. Journal of Animal Science, 55(6):1272-1283.

Fitzgerald J and Butler WR. (1982). Seasonal effects and hormonal patterns related to puberty in ewe lambs. Biology of Reproduction, 27:853-863. 
Fogarty NM, Brash LD, and Gilmour AR. (1994). Genetic parameters for reproduction and lamb production and their components and liveweight, fat depth, and wool production in Hyfer sheep. Australian Journal of Agricultural Research, 45:443-457.

Forrest PA, and Bichard M. (1974). Analysis of produciton records from a lowland sheep flock 2. Flock statistics and reproductive performance. Animal Production, 25-32.

Foster DL. (1984). Preovulatory gonadotropin surge system of prepubertal female sheep is exquisitely sensitive to the stimulatory feedback action of estradiol. Endocrinology, 115:1186-1189.

Foster DL and Nagatani S. (1999). Physiological perspectives on leptin as a regulator of reproduction: Role in timing puberty. Biology of Reproduction, 60:205-215.

Foster DL, and Karsch FJ. (1975). Development of the mechanism regulating the preovulatory surge of luteinizing hormone in sheep. Endocrinology, 97:1205-1209.

Foster DL, and Olster DH. (1985). Effect of restricted nutrition on puberty in the lamb: patterns of tonic luteinizing hormone (LH) secretion and competency of the LH surge system. Endocrinology, 116:375-381.

Foster DL, and Ryan KD. (1979). Endocrine mechanisms governing transition into adulthood: A marked decrease in inhibitory feedback action of estradiol on tonic secretion of luteinizing hormone in the lamb during puberty. Endocrinology, 105:896-904.

Foster DL, and Ryan KD. (1981). Endocrine mechanisms governing transition into adulthood in the female sheep. Journal of Reproduction and Fertility Supplement, 30:75-90.

Foster DL, Ebling FJ, Vannerson LA, Wood RI, and Fenner DE. (1988). Regulation of puberty in the lamb: Internal and external cues. Progress in Endocrinology Volume 2, Amsterdam: Elsevier, 861-866.

Foster DL, Farsch FJ, Olster DH, Ryan KD, and Yellon SM. (1986). Determinants of puberty in a seasonal breeder. Recent Progress in Hormone Research, 42:331-384.

Foster DL, Jaffe RB, and Niswender GD. (1975b). Sequential patterns of circulating LH and FSH in female sheep during the early postnatal period: Effect of gonadectomy. Endocrinology, 96:15-22.

Foster DL, Lemons JA, Jaffe RB, and Niswender GB. (1975). Sequential patterns of circulating luteinizing hormone and follicle-stimulating hormone in female sheep from early postnatal life through the first estrous cycles. Endocrinology, 97:985-994.

Foster DL, Ryan KD, and Papkoff H. (1984). Hourly administration of luteininzing hormone induces ovulation in prepubertal female sheep. Endocrinology, 115:1179-1185.

Foster DL, Yellon SM, and Olster DH. (1985). Internal and external determinants of the timing of puberty in the female. Journal of Reproduciton and Fertility, 75:327-344.

Friedman CR, I'Anson H, and Manning JM. (1992). Acute and chronic inhibitory feedback of physiological concentrations of estradil on LH pulse frequency in the prepubertal female sheep. Biology of Reproduction, 46(Suppl 1) Abstract 117.

Frisch RE, and McArthur JW. (1974). Menstrual Cycles: Fatness as a determinant of minimum weight for height necessary for their maintenance or onset. Science, 185(4155):949-951. 
Gaskins CT, Snowder GD, Westman MK, and Evans M. (2005). Influence of body weight, age, and weight gain on fertility and prolificacy in four breeds of ewe lambs. Journal of Animal Science, 83(7), 1680-1689.

Geisler PA and Fenlon JS. (1979). The effect of body weight and its components on lambing performance in some commercial flocks in Britain. Animal Production, 28:245-255.

Goodman RL. (1994). Neuroendocrine control of the ovine estrous cycle. In The Physiology of Reproduction (pp. 659-709). New York: Raven Press.

Hafez ESE. (1952). Studies on the breeding season and reproduction of the ewe, Parts I-V. The Journal of Agricultural Science, 42:189-265.

Hakansson ML, Brown H, Ghilardi N, Skoda RC, and Meister B. (1998). Leptin receptor immunoreactivity in chemically defined target neurons of the hypothalamus. Journal of Neuroscience, 18:559-572.

Hall JB, Staigmiller RB, Short RE, Bellows RA, MacNeil MD, and Bellows SE. (1997). Effect of age and pattern of gain on induction of puberty with a progestin in beef heifers. Journal of Animal Science, 75:1606-1611.

Hansel W, and Convey EM. (1983). Physiology of the estrous cycle. Journal of Animal Science, 57(2):404-424.

Hare L, and Bryant MJ. (1985). Ovulation rate and embryo survival in young ewes mated either at puberty or at the second or third oestrus. Animal Reproduction Science, 8:41-52.

Hawker H and Kennedy J. (1978). Puberty and subsequent oestrous activity in young Merino ewes. Australian Journal of Experimental Agriculture and Animal Husbandry, 18:347-354.

Herbison AE, Robinson JE, and Skinner DC. (1993). Distribution of estrogen receptor-immunoreactive cells in the preoptic area of the ewe: Co-localization with glutamic acid decarboxylase but not luteinizing hormone-releasing hormone. Neuroendocrinology, 57(4):751-759.

Hudgens RE, Martin TG, Diekman MA, and Waller SL. (1987). Reproductive performance of suffolk and suffolk-cross ewes and ewe lambs exposed to vasectomized rams before breeding. Journal of Animal Science, 65:1173-1179.

Huffman LK, Inskeep EK, and Goodman RL. (1987). Changes in episodic luteinizing hormone secretion leading to puberty in the lamb. Biology of Reproduction, 37:755-761.

Hulet CV, Wiggins EL, and Ercanbrack SK. (1969). Estrus in range lambs and its relationship to lifetime reproductive performance. Journal of Animal Science, 28:246-252.

Jorgez CJ, Klysik M, Jamin SP, Behringer RR, and Matzuk MM. (2004). Granulosa cell-specific inactivation of follistatin causes female fertility defects . Molecular Endocrinology, 18:953-967.

Joubert DM. (1963). Puberty in female farm animals. Animal Breeding Abstracts, 31:295-306.

Jurgens MH, Bregendahl K, Coverdale JA, and Hansen SL. (2012). Animal Feeding and Nutrition. Dubuque, IA: Kendall Hunt Publishing Company. 
Kadokawa H, Matsui M, Hayashi K, Matsunaga N, Kawshima C, Shimizu T, Kida K, and Miyamoto A. (2008). Peripheral administration of kisspeptin-10 increases plasma concentrations of GH as well as LH in prepubertal Holstein heifers. Journal of Endocrinology, 196:331-334.

Keisler DH, Inskeep EK, and Dailey RA. (1985). Roles of pattern of secretion of luteinizing hormone and the ovary in attainment of puberty in ewe lambs. Domestic Animal Endocrinology, 2:123-132.

Kennedy JP, Worthington CA, and Cole ER. (1974). The postnatal development of the ovary and uterus of the Merino lamb. Journal of Reproduction and Fertility, 36:275-282.

Kenyon PR, Morel PC, Morris ST, Burnham DL, and West DM. (2006). The effect of length of use of teaser rams prior to mating and individual liveweight on reproductive performance of ewe hoggets. New Zealand Veterinary Journal, 54(2):91-95.

Kenyon PR, Morel PCH, and Morris ST. (2004a). The effect of individual liveweight and condition scores of ewes at mating on reproductive and scanning performance. New Zealand Veterinary Journal, 52:230-235.

Kenyon PR, Morris ST, and West DM. (2008). Can Romney rams whose scrotum has been shortened by the use of a rubber ring be used as an alternative to vasectomised Perendale rams for inducing early breeding activity in Romney ewe lambs? New Zealand Veterinary Medicine, 56:326-329.

Kenyon PR, Morris ST, and West DM. (2010). Proportion of rams and the condition of ewe lambs at joining influences their breeding performance. Animal Production Science, 50:454-459.

Kenyon PR, Perkins NR, Pinchbeck GL, Morris ST, and West DM. (2004b). Identifying factors which maximise the lambing performance of hoggets: a cross sectional study. New Zealand Veterinary Journal , 52:371-377.

Kenyon PR, Smith SL, Morel PC, Morris ST, and West DM. (2009). The effect of the maturity and prior breeding activity of rams and body condition score of ewe hoggets on the reproductive performance of ewe hoggets. New Zealand Veterinary Journal, 57(5):290-294.

Kenyon PR, Thompson AN, and Morris ST. (2014). Breeding ewe lambs successfully to improve lifetime performance. Small Ruminant Research, 118:2-15.

Kenyon PR, Vinoles C, and Morris ST. (2012). Effect of teasing by the ram on the onset of puberty in Romney ewe lambs. New Zealand Journal of Agricultural Research, 55(3):283-291.

Khan TH, Beck NFG, and Khalid M. (2009). The effect of hCG treatment on day 12 post-mating on ovarian function and reproductive performance of ewe lambs. Animal Reproduction Science, 116:162-168.

Khan TH, Hastie PM, Beck NFG, and Khalid M. (2003). hCG treatment on day of mating improves embryo viability and fertility in ewe lambs. Animal Reproduction Science, 76: 81-89.

Kieborz-Loos KR, Garverick HA, Keisler DH, Hamilton SA, Salfen BE, Youngquist RS, and Smith MF. (2003). Oxytocin-induced secretion of prostaglandin F2 $\alpha$ in postpartum beef cows: Effects of progesterone and estradiol-17 $\beta$ treatment. Journal of Animal Science, 81:1830-1836.

Kimura F, Sidis Y, Bonomi L, Xia Y, and Schneyer A. (2010). The follistatin-288 isoform alone is sufficient for survival but not for normal fertility in mice. Endocrinology, 151:1310-1319. 
Klenke U, Constantin S, and Wray S. (2010). Neuropeptide Y directly inhibits neuronal activity in a subpopulation of gonadotropin-releasing hormone-1 neurons via Y1 receptors. Endocrinology, 151:2736-2746.

Knights M, Baptiste QS, and Lewis PE. (2002). Ability of ram introduction to induce LH secretion, estrus and ovulation in fall-born ewe lambs during anestrus. Animal Reproduction Science, 69: 199-209.

Knights M, Hoehn T, Lewis PE, and Inskeep EK. (2001). Effectiveness of intravaginal progesterone inserts and FSH for inducing synchronized estrus and increasing lambing rate in anestrous ewes. Journal of Animal Science, 79:1120-1131.

Kochhar HPS, Wu B, Morris LHA, Buckrell BC, Pollard JW, Basrur PK, and King WA. (2002). Maturation status, protein synthesis and developmental competence of oocytes derived from lambs and ewes. Reproduction in Domestic Animals, 37: 19-25.

Land RB, Thimonier J, and Pelletier J. (1970). Possibility of the induction of LH secretion by injection of estrogen in the female lamb as a function of age. Comptes Rendus Hebdomadaires Des Seances, 271:1549-1551.

Lents CA, Heidorn NL, Barb CR, and Ford JJ. (2008). Central and peripheral administration of kisspeptin activates gonadotropin but not somatotropin secretion in prepubertal gilts. Reproduction, 135:879-887.

Levine JM, Vavra M, Phillips R, and Hohenboken W. (1978). Ewe lamb conception as an indicator of future production in farm flock Columbia and Targhee ewes. Journal of Animal Science, 46:1925.

Li C, Chen P, and Smith MS. (1999). Morphological evidence for direct interaction between arcuate nucleus neuropeptide Y (NPY) neurons and gonadotropin-releasing hormone neurons and the possible involvement of NPY Y1 receptors. Endocrinology, 140:5382-5390.

Luque RM, Kineman RD, and Tena-Sempere M. (2007). Regulation of hypothalamic expression of KiSS1 and GPR54 genes by metabolic factors: analysis using mouse models and a cell line. Endocrinology, 148:4601-4611.

Mackey DR, Wylie ARG, Sreenan JM, Roche HF, and Diskin MG. (2000). The effect of acute nutritional changes on follicle wave turnover, gonadotropin and steroid concentration in beef heifers. Nutrition, 78(2):429-442.

Manning JM, Herbosa CG, Pelt J, Karsch F, and Foster DL. (1993). Pattern of GnRH secretion int the pituitary portal circulation of the female sheep during puberty. Twenty-Third Annual Meeting of the Society for Neuroscience, Washington, D.C. (Abst. 258.2).

Mansour AM. (1959). The hormonal control of ovulation in the immature lamb. Journal of Agricultural Science, 52:87-94.

McLeod BJ, and Haresign W. (1984). Evidence that progesterone may influence subsequent luteal function in the ewe by modulating preovulatory follicle development. Journal of Reproduction and Fertility, 71:381-386.

McMillan WH, and McDonald MF. (1983). Reproduction in ewe lambs and its effects on 2-year-old performance. New Zealand Journal of Agricultural Research, 26: 437-442. 
Menassol JB, Collet A, Chesneau D, Malpaux B, and Scaramuzzi RJ. (2012). The interaction between photoperiod and nutrition and its effects on seasonal rhythms of reproduction in the ewe. Biology of Reproduction, 86(2):52, 1-12.

Mulvaney FJ, Kenyon PR, Morris ST, and West DM. (2008). Ewe lamb nutrition during pregnancy affects pregnancy outcome. Australian Journal of Exerimental Agriculture, 48(8):1085-1089.

Mulvaney FJ, Morris ST, Kenyon PR, Morel PCH, and West DM. (2012). Effect of nutrition from midpregnancy to parturition on the liveweight of twin-bearing hoggets and the liveweight and survival of their lambs. New Zealand Journal of Agricultural Research, 55(4):358-392.

Mulvaney FJ, Morris ST, Kenyon PR, Morel PCH, West DM, Vinoles C, and Glover KMM. (2013). Comparison between the reproductive performance of ewe hoggets and mature ewes following a progesterone-based oestrus synchronization protcol. New Zealand Journal of Agricultural Research, 56(4): 288-296.

Navarro VM, Fernandez-Fernandez R, Castellano JM, Roa J, Mayen A, Barreiro ML, Gaytan F, Aguilar E, Pinilla L, Dieguez C .... (2004). Advanced vaginal opening and precocious activation of the reproductive axis by KiSS-1 peptide, the endogenous ligand of GPR54. Journal of Physiology, 561:379-386.

Nephew KP, Carenas H, McClure KE, Ott TL, Bazer FW, and Pope WF. (1994). Effects of administration of human chorionic gonadotropin or pregesterone before maternal recognition of pregnancy on blastocyst development and pregnancy in sheep. Journal of Animal Science, 72:453-458.

Nestor CC, Briscoe AMS, Davis SM, Valent M, Goodman RL, and Hileman SM. (2012). Evidence of a role for kisspeptin and neurokinin B in puberty of female sheep. Neuroendocrinology, 153(6):2756-2765.

O'Brien JK, Dwarte D, Ryan JP, Maxwell WM, and Evans G. (1996). Developmental capacity, energy metabolism and ultrastructure of mature oocytes from prepubertal and adult sheep. Reproduction, Fertility, and Development, 8(7):1029-1037.

Ott TL, Mirando LA, Davies MA, and Bazer FW. (1992). Effects of ovine conceptus secretory proteins and progesterone on oxytocin-stimulated endometrial production of prostaglandin and turnover of inositol phosphate in overiectomized ewes. Journal of Reproduction and Fertility, 95:19-29.

Padmanabhan V, Battaglia D, Brown MB, Karsch FJ, Lee JS, Pan W, Phillips DJ, and Van Cleeff J. (2002). Neuroendocrine control of follicle-stimulating hormone (FSH) secretion. II. Is follistatininduced suppression of FSH secretion mediated via changes in activin availability and does it involve changes in gonadotropin-releasing hormone secretion? Biology of Reproduction, 66:1395-1402.

Pearce DT, and Robinson TJ. (1985). Plasma progesterone concentrations, ovarian endocrinological responses and sperm transport in ewes with synchronized estrus. Journal of Reproduction and Fertility, 75:29-33.

Pierroz DD, Gruaz NM, d'Alleves V, and Aubert ML. (1995). Chronic administration of neuropeptide Y into the lateral ventricle starting at 30 days of life delays sexual maturation in the female rat. Neuroendocrinology, 61:293-300. 
Quirke JF. (1978). Reproductive performance of Galway, Finnish, Landrace, and Fill-cross ewe lambs. Irish Journal of Agricultural Research, 17:25-32.

Quirke JF and Hanrahan JP. (1977). Comparison of the survival in the uteri of adult ewes of cleaved ova from adult ewes and ewe lambs. Journal of Reproduction and Fertility, 51, 487-498.

Ramirez DV and McCann SM. (1963). Comparison of the regulation of luteinizing hormone (LH) secretion in immature and adult rats. Endocrinology, 71:452-464.

Ramirez-Godinez JA, Kiracofe GH, McKee RM, Schalles RR, and Kittok RJ. (1981). Reducing the incidence of short estrous cycles in beef cows with norgestomet. Theriogenology, 15(6):613-623.

Ramirez-Godinez JA, Kiracofe GH, Schalles RR, and Niswender GD. (1982). Endocrine patterns in the postpartum beef cow associated with weaning: A comparison of the short and subsequent normal cycles. Journal of Animal Science, 55(1):153-158 .

Redmond JS, Baez-Sandoval GM, Spell KM, Spencer TE, Lents CA, Williams GL, and Amstalden M. (2011a). Developmental changes in hypothalamic Kiss1 expression during activation of the pulsatile release of luteinising hormone in maturing ewe lambs. Journal of Neuroendocrinology, 23:815-822.

Redmond JS, Macedo GG, Velez IC, Caraty A, WIlliams GL, and Amstalden M. (2011b). Kisspeptin activates the hypothalamic-adenohypophyseal-gonadal axis in prepubertal ewe lambs. Reproduction, 141:541-548.

Robinson TJ. (1955). Endocrine relationships in the induction of oestrus and ovulation in the anestrous ewe. Journal of Agricultural Science, 46:37-43.

Rosales Nieto CA, Ferguson MB, Macleay CA, Briegel JR, Martin GB, and Thompson AN. (2013a). Selection for superior growth advaces the onset of puberty and increases reproductive performance in ewe lambs. Animal, 7(6): 990-997.

Rosales Nieto CA, Ferguson MB, Macleay CA, Briegel JR, Wood DA, Martin GB, and Thompson AN. (2013b). Ewe lambs with higher breeding values for growth achieve higher reproductive performance when mated at age 8 months. Theriogenology, 80:427-435.

Rosales Nieto CA, Thompson AN, Macleay CA, Briegel JR, Hedger MP, Ferguson MB, and Martin GB. (2014). Relationships among body composition, circulating concentrations of leptin and follistatin, and the onset of puberty and fertility in young female sheep. Animal Reproduction Science, 151:148-156.

Russel AJF, Doney JM and Gunn RG. (1969). Subjective assessment of body fat in live sheep. Journal of Agriculture Science, 72:541-545.

Safari E, Fogarty NM, Gilmour AR, Atkins KD, Mortimer SI, Swan AA, Brien FD, Greeff JC, and van der Werf JHJ. (2007). Genetic correlations among and between wool, growth, and reproduction traits in Merino sheep. Journal of Animal Breeding and Genetics, 124:65-72.

Samadi F, Blache D, Martin GB, and D'Occhio MJ. (2014). Nutrition, metabolic profiles and puberty in Brahman (Bos indicus) beef heifers. Animal reproduction science, 146:134-142. 
Sanson DW, West TR, Tatman WR, Riley ML, Judkins MB, and Moss GE. (1993). Relationship of body composition of mature ewes with conditoin score and body weight. Journal of Animal Science, 71:1112-1116.

Saoud ND and Hohenboken WD. (1984). Phenotypic relationships among early life traits and lifetime ewe production efficiency. Journal of Animal Science, 59(3):607-619.

Sawalha MN, Kridli RT, Jawasreh KI, and Meza-Herrera CA. (2011). The use of melatonin and progestagen-eCG to initiate reproductive activity in prepubertal Awassi ewe lambs. Tropical Animal Health and Production, 43:1345-1350.

Schillo KK, Hall JB, and Hileman SM. (1992). Effects of nutrition and season on the onset of puberty in the beef heifer. Journal of Animal Science, 70:3994.

Schneider JE and Wade GN. (2000). Reproduction inhibition in service of energy balance. In E. K. Schneider, Reproduction in Context (pp. 34-82). Boston: MIT Press.

Smith JT, Coolen LM, Kriegsfeld LJ, Sari IP, Jaafarzadehshirazi MR, Maltby M, Bateman K, Goodman RL, Tilbrook AJ, Ubuka T, Bentley GE, Clarke IJ, and Lehman MN. (2008). Variation in kisspeptin and RFamide-related peptide (RFRP) expression and terminal connections to gonadotropin-releasing hormone neurons in the brain: a novel medium for seasonal breeding in the sheep. Endocrinology, 146:5770-5782.

Squires El, Scaramuzzi RJ, Caldwell BV, and Inskeep EK. (1972). LH release and ovulation in the prepubertal lamb. Journal of Animal Science, 34:612-614.

Stellflug JN, Hatfield GP, Wulster-Radcliff MC, and Walker JW. (2001). Reproductive performance of ewe lambs from ewes from different selection practices with or without induced estrus. Animal Reproduction and Science, 66:185-193.

Tillet Y, Picard S, Bruneau G, Ciofi P, Wankowska M, Wojcik-Gladysz A, and Polkowska J. (2010). Hypothalamic acuate neuropeptide Y-neurons decrease periventricular somatostatin-neuronal activity before puberty in the female lamb: morphological arguments. Journal of Chemical Neuroanatomy, 40:265-271.

Tran CT, Edey TN, and Findlay JK. (1979). Pituitary response of prepubertal lambs to oestradiol-17B. Australian Journal of Biological Science, 32:463-467.

Ueno N, Ling N, Ying SY, Esch F, Shimasaki S, and Guillemin R. (1987). Isolation and partial characterization of follistatin: A single-chain $\mathrm{Mr}$ 35,000 monomeric protein that ihibits the release of follicle-stimulating hormone. Proceedings of the National Academy of Sciences of the United States of America, 84:8282-8286.

Ungerfeld R, Forsberg M, and Rubianes E. (2004). Overveiw of the response of anoestrous ewes to the ram effect. Reproduction Fertility and Development, 16(4):479-490.

Villa-Godoy A, Hughes TL, Emery RS, Stanisiewski EP, and Fogwell RL. (1990). Influence of energy balance and body condition on estrus and estrous cycles in holstein heifers. Journal of Dairy Science, 73(10):2759-2765.

Wettman RP. (1980). Postpartum endocrine function of cattle, sheep and swine. Journal of Animal Science, 2:2-15. 
Wilmut I, Sale DI, and Ashworth JC. (1995). The influence of variation in embryo stage and maternal hormone profiles on embryo production in farm animals. Theriogenology, 107-119.

Worthington CA, and Kennedy JP. (1979). Ovarian response to exogenous hormones in six-week-old lambs. Austrailian Journal of Biological Sciences, 32:91-95.

Xiao CW and Goff AK. (1999). Hormonal regulation of oestrogen and progesterone receptors in cultured bovine endometrial cells. Journal of Reproduction and Fertility, 115:101-109.

Yellon SM and Foster DL. (1986). Melatonin rhythms time photoperiod induced puberty in the female lamb. Endocrinology, 119:44-49.

Zelinski MB, Hirota NA, Keenan EJ, and Stormshak F. (1980). Influence of exogenous estradiol-17 $\beta$ on endometrial progesterone and estrogen receptors during the luteal phase of the ovine estous cycle. Biology of Reproduction, 23:743-751.

Zollers WG, Garverick HA, Smith MF, Moffatt RJ, Salfen BE, and Youngquist RS. (1993). Concentrations of progesterone and oxytocin receptors in endometrium of postpartum cows expected to have a short or normal oestrous cycle. Journal of Reproduction and Fertility, 97:329337. 


\section{Vita}

\section{Sarah Nancy Carr}

Birthplace:

Knoxville, Tennessee

Date of Birth:

October 12, 1992

\section{Schools Attended:}

Sevierville Primary School: Sevierville, Tennessee

Sevierville Intermediate School: Sevierville, Tennessee

Sevierville Middle School: Sevierville, Tennessee

Sevier County High School: Sevierville, Tennessee

Pigeon Forge High School: Pigeon Forge, Tennessee

Berea College: Berea, Kentucky

Universidad Veritas: San Jose, Costa Rica

West Virginia University: Morgantown, West Virginia

\section{Degrees Received:}

Bachelor of Science in Agriculture and Natural Resources, Berea College, 2015

Master of Science in Animal Physiology, West Virginia University, 2018 